\title{
The influence of ice sheets on temperature during the past 38 million years inferred from a one-dimensional ice sheet-climate model
}

\author{
Lennert B. Stap ${ }^{1, a}$, Roderik S. W. van de Wal ${ }^{1}$, Bas de Boer ${ }^{1}$, Richard Bintanja ${ }^{2}$, and Lucas J. Lourens ${ }^{3}$ \\ ${ }^{1}$ Institute for Marine and Atmospheric Research Utrecht (IMAU), Utrecht University, Princetonplein 5, \\ 3584 CC Utrecht, the Netherlands \\ ${ }^{2}$ Royal Netherlands Meteorological Institute (KNMI), Utrechtseweg 297, 3731 GA De Bilt, the Netherlands \\ ${ }^{3}$ Department of Earth Sciences, Faculty of Geosciences, Utrecht University, Heidelberglaan 2, \\ 3584 CS Utrecht, the Netherlands \\ anow at: Alfred Wegener Institute, Helmholtz Centre for Polar and Marine Research (AWI), Bussestrasse 24, \\ 27570 Bremerhaven, Germany
}

Correspondence to: Lennert B. Stap (1.b.stap@uu.nl, lennert.stap@awi.de)

Received: 28 October 2016 - Discussion started: 8 November 2016

Revised: 21 August 2017 - Accepted: 23 August 2017 - Published: 25 September 2017

\begin{abstract}
Since the inception of the Antarctic ice sheet at the Eocene-Oligocene transition ( $\sim 34 \mathrm{Myr}$ ago), land ice has played a crucial role in Earth's climate. Through feedbacks in the climate system, land ice variability modifies atmospheric temperature changes induced by orbital, topographical, and greenhouse gas variations. Quantification of these feedbacks on long timescales has hitherto scarcely been undertaken. In this study, we use a zonally averaged energy balance climate model bidirectionally coupled to a one-dimensional ice sheet model, capturing the ice-albedo and surface-height-temperature feedbacks. Potentially important transient changes in topographic boundary conditions by tectonics and erosion are not taken into account but are briefly discussed. The relative simplicity of the coupled model allows us to perform integrations over the past $38 \mathrm{Myr}$ in a fully transient fashion using a benthic oxygen isotope record as forcing to inversely simulate $\mathrm{CO}_{2}$. Firstly, we find that the results of the simulations over the past $5 \mathrm{Myr}$ are dependent on whether the model run is started at 5 or $38 \mathrm{Myr}$ ago. This is because the relation between $\mathrm{CO}_{2}$ and temperature is subject to hysteresis. When the climate cools from very high $\mathrm{CO}_{2}$ levels, as in the longer transient $38 \mathrm{Myr}$ run, temperatures in the lower $\mathrm{CO}_{2}$ range of the past $5 \mathrm{Myr}$ are higher than when the climate is initialised at low temperatures. Consequently, the modelled $\mathrm{CO}_{2}$ concentrations depend on the initial state. Taking the realistic warm initialisa-
\end{abstract}

tion into account, we come to a best estimate of $\mathrm{CO}_{2}$, temperature, ice-volume-equivalent sea level, and benthic $\delta^{18} \mathrm{O}$ over the past $38 \mathrm{Myr}$. Secondly, we study the influence of ice sheets on the evolution of global temperature and polar amplification by comparing runs with ice sheet-climate interaction switched on and off. By passing only albedo or surface height changes to the climate model, we can distinguish the separate effects of the ice-albedo and surfaceheight-temperature feedbacks. We find that ice volume variability has a strong enhancing effect on atmospheric temperature changes, particularly in the regions where the ice sheets are located. As a result, polar amplification in the Northern Hemisphere decreases towards warmer climates as there is little land ice left to melt. Conversely, decay of the Antarctic ice sheet increases polar amplification in the Southern Hemisphere in the high- $\mathrm{CO}_{2}$ regime. Our results also show that in cooler climates than the pre-industrial, the ice-albedo feedback predominates the surface-heighttemperature feedback, while in warmer climates they are more equal in strength. 


\section{Introduction}

The most abundant information with the highest resolution on Cenozoic global climate change is provided by stacked benthic oxygen isotope $\left(\delta^{18} \mathrm{O}\right)$ records (Lisiecki and Raymo, 2005; Zachos et al., 2008; Cramer et al., 2009), which have been well studied and statistically analysed (e.g. Mudelsee et al., 2014). The benthic $\delta^{18} \mathrm{O}$ signal is known to be comprised of two factors (e.g. Chappell and Shackleton, 1986): (1) the deep sea temperature and (2) the volume of land ice on Earth. An additional independent record of either one is therefore required to separate the signal into its individual constituents. Deep sea temperature records can be reconstructed based on the $\mathrm{Mg} / \mathrm{Ca}$ proxy (Lear et al., 2000; Sosdian and Rosenthal, 2009; Elderfield et al., 2012), but a global average deep sea temperature is hard to obtain. Sea level records are also available but are subject to the same problem of inferring a global mean (Miller et al., 2005; Kominz et al., 2008; Rohling et al., 2014). Studies using sea level records face the additional challenge of converting local sea level to ice volume, which is not straightforward mainly because of dynamic topography (Mitrovica and Milne, 2003; Kendall et al., 2005). Alternatively, calculation of benthic $\delta^{18} \mathrm{O}$ can be incorporated in coupled ice sheet-climate models by using parameterisations of the contribution of deep sea temperature (Duplessy et al., 2002) and the isotopic content of ice sheets (Cuffey, 2000). Hitherto, studies using this approach have mostly focused on relatively short time intervals surrounding important climatic events, such as the EoceneOligocene transition (33.9 Myr ago; Tigchelaar et al., 2011; Ladant et al., 2014; Wilson et al., 2013), the mid-Miocene climatic optimum (13.9 Myr ago; Langebroek et al., 2010; Gasson et al., 2016), and the Pliocene-Pleistocene transition (2.6 Myr ago; Willeit et al., 2015) using models of varying complexity. These studies have provided valuable information because they have simulated these key events in great detail. However, they do not describe climate change on multimillion-year timescales and prove consistency by transiently simulating multiple events using the same set-up. This is mainly due to insufficient computer power. An effort was made to simulate the past $3 \mathrm{Myr}$ using a model of reduced complexity (Berger et al., 1999), but they did not include the Southern Hemisphere and the Antarctic ice sheet in their model. Here, we will use a coupling between an energy balance global climate model and a one-dimensional ice sheet model of all major ice sheets to perform transient simulations over the past $38 \mathrm{Myr}$. By focusing on the long-term evolution of climate, we provide a complementary approach to snapshot and short time slice experiments of more complex models.

Our model approach builds on the inverse routine to derive atmospheric temperature from benthic $\delta^{18} \mathrm{O}$, which was introduced by Oerlemans (2004). This methodology was consequently developed further to force stand-alone threedimensional ice sheet models over the past $1 \mathrm{Myr}$ (Bintanja et al., 2005; De Boer et al., 2013), the past 3 Myr (Bintanja and Van de Wal, 2008), and the past $5 \mathrm{Myr}$ (De Boer et al., 2014). With this inverse routine, the past $40 \mathrm{Myr}$ were simulated (De Boer et al., 2010) and further analysed (De Boer et al., 2012) using a one-dimensional ice sheet model that calculates all land ice on Earth. In Stap et al. (2014), this ice sheet model was coupled to a zonally averaged energy balance climate model (Bintanja, 1997) and run over the past $800 \mathrm{kyr}$ forced by a compiled ice core $\mathrm{CO}_{2}$ record (Petit et al., 1999; Siegenthaler et al., 2005; Lüthi et al., 2008). Inclusion of a climate model added $\mathrm{CO}_{2}$ to global temperature and sea level as an integrated component of the simulated system. In addition, it rendered the possibility of investigating ice sheetclimate interactions, specifically the ice-albedo and surfaceheight-temperature feedbacks. Furthermore, instead of annual mean and globally uniform temperature perturbations to present-day climate, seasonal meridional temperature distributions were used to force the different ice sheets. In a subsequent study, the inverse routine was transformed to yield $\mathrm{CO}_{2}$ concentrations using the benthic $\delta^{18} \mathrm{O}$ as input, making $\mathrm{CO}_{2}$ a prognostic variable (Stap et al., 2016a). The resulting values were used to force the coupled model over the past 5 Myr. In Stap et al. (2016b), the model was run over the period 38 to $10 \mathrm{Myr}$ ago, and the influence of Antarctic topographic changes on the simulated $\mathrm{CO}_{2}$ was investigated. In this study, however, changes in topographic boundary conditions are not included, although their effect is briefly discussed.

Here, we will use this coupled ice sheet-climate model forced by benthic $\delta^{18} \mathrm{O}$ to transiently simulate the entire past $38 \mathrm{Myr}$. We recognise that our simulation of $\mathrm{CO}_{2}$ may be improved in subsequent studies that include geological processes that are still missing in our model set-up. For instance, tectonics leading to mountain uplift (Kutzbach et al., 1993) and closure of sea ways (Kennett, 1977; Toggweiler and Bjornsson, 2000; Hamon et al., 2013), erosion (Wilson et al., 2012; Gasson et al., 2015; Stap et al., 2016b), and vegetation changes (Knorr et al., 2011; Liakka et al., 2014; Hamon et al., 2012) may have affected the climate system during the past $38 \mathrm{Myr}$. Here, we will purely focus on the influence of ice sheets on the climate, in particular the relation between $\mathrm{CO}_{2}$ and temperature, during this time. Earlier studies using more complex stand-alone ice sheet models and coupled ice sheet-climate models have, for example, determined the $\mathrm{CO}_{2}$ thresholds for the glaciation of Antarctica (DeConto and Pollard, 2003; Langebroek et al., 2010; Ladant et al., 2014; Gasson et al., 2014) and the Northern Hemisphere (DeConto et al., 2008; Hamon et al., 2013). Furthermore, they have investigated the hysteresis in the relation between ice volume and $\mathrm{CO}_{2}$ (Pollard and DeConto, 2005) and the behaviour of the Antarctic ice sheet during the Oligocene (Pollard et al., 2013) and Plio-Pleistocene (Pollard and DeConto, 2009). Our model represents reduced complexity in the model hierarchy (see e.g. Pollard, 2010, for a discussion), and adds a long-term transient perspective on the evolution of 


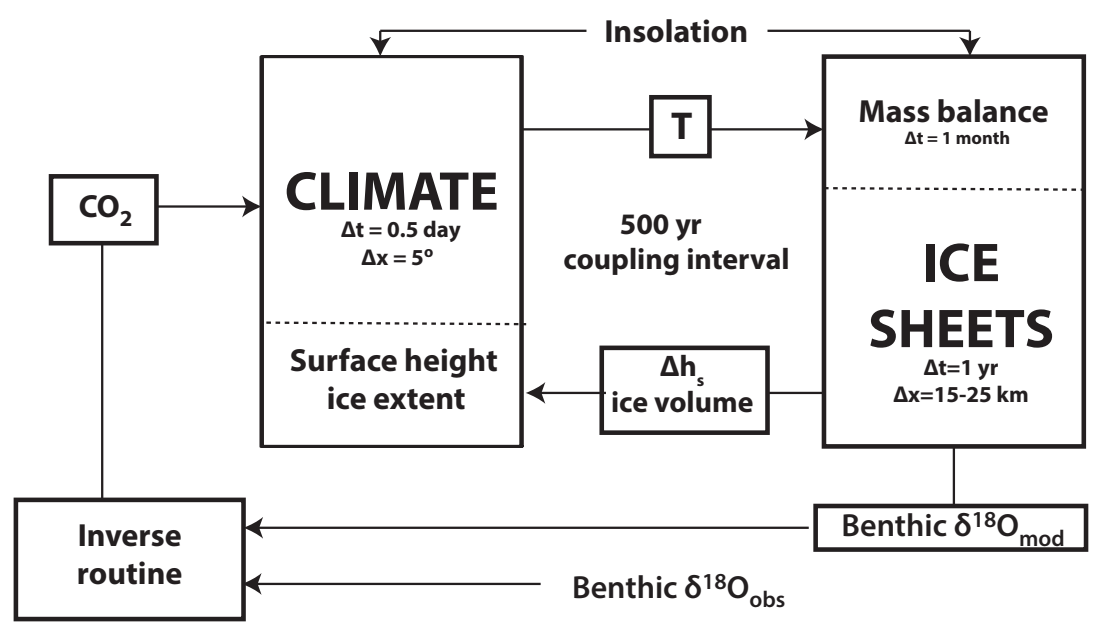

Figure 1. Schematic overview of the coupling of the zonally averaged energy balance climate model and the one-dimensional ice sheet model.

ice sheets and the climate. It reconciles knowledge on benthic $\delta^{18} \mathrm{O}, \mathrm{CO}_{2}$, sea level, and temperature. However, it lacks ice shelf dynamics and sophisticated grounding line parameterisations that have been shown to be important at least on short timescales (Pollard and DeConto, 2012; Pollard et al., 2015). Therefore, this study should be seen as a first step in the direction of simulating multi-million-year time spans with coupled ice sheet-climate models, aiming to combine temperature, sea level, and $\mathrm{CO}_{2}$ in one framework. As such, its goal is two-fold. Firstly, as a precursory study, we attempt to identify interesting phenomena and potential obstacles and set a reference simulation over the past $38 \mathrm{Myr}$. When results of more sophisticated models are achieved, they can be compared to ours to see which features appear in the full hierarchy of models and which are specific to more comprehensive models including more physics. Secondly, we perform multiple $38 \mathrm{Myr}$ integrations of our coupled model with ice sheetclimate interactions switched on and off. This allows us to quantify the effect of these interactions on global temperature perturbations and polar amplification, distinguishing between the ice-albedo and the surface-height-temperature feedback.

\section{Model}

We use the same simplified coupled ice sheet-climate model set-up as Stap et al. (2016b) (Fig. 1). The climate component is a zonally averaged energy balance climate model (based on North, 1975; Bintanja, 1997) with $5^{\circ}$ of latitudinal and 0.5day temporal resolution. It includes a simple ocean model that has six vertical layers and mimics meridional ocean circulation with varying strength based on the density difference between the polar and equatorial waters. Sea ice cover is calculated thermodynamically at $1.25^{\circ}$ of resolution. The climate model provides the local monthly temperature input
$(T)$ to the mass balance module of one-dimensional models of the five major Cenozoic ice sheets (Eurasian, North American, Greenland, West Antarctic, and East Antarctic ice sheets) (De Boer et al., 2010). Herein, accumulation follows as a temperature-dependent fraction of precipitation $(P)$ :

$P=P_{0} e^{0.04 T-R / R_{\mathrm{c}}}$,

where $P_{0}$ is present-day precipitation, $R$ is ice sheet radius, and $R_{\mathrm{c}}$ is an ice-sheet-dependent critical radius. An insolation-temperature melt formulation is used to calculate ablation:

$M=\left[10 T+0.513(1-\alpha) Q+C_{\mathrm{abl}}\right] / 100$.

Here, $\alpha$ is surface albedo, and $Q$ is local radiation obtained from Laskar et al. (2004). Ice-sheet-dependent tuning factors $C_{\text {abl }}$ determine the thresholds for which ablation starts. The tuning targets and consequent values for $C_{\mathrm{abl}}$ have been described in Stap et al. (2014). The influence of this parameter for inception of the East Antarctic ice sheet has been discussed in Stap et al. (2016b), who showed that changing the value from -30 to -5 results in glacial inception at roughly $450 \mathrm{ppm}$ instead of $700 \mathrm{ppm}$. The ice sheet models calculate the surface height change and ice sheet extent using the shallow ice approximation with 15 to $25 \mathrm{~km}$ of resolution depending on the ice sheet (De Boer et al., 2010). This information is used to update the land ice fraction and surface height profile in the climate model for the next time step. Exchange of variables takes place every 500 model years, constituting the output timestep of the coupled model. The isotopic content of the ice sheets is calculated using the parameterisation of Cuffey (2000):

$\delta^{18} \mathrm{O}_{\mathrm{i}}=\delta^{18} \mathrm{O}_{\mathrm{PD}}+\beta_{T} \Delta T+\beta_{Z} \Delta Z$,

where $\beta_{T}$ and $\beta_{Z}$ are ice-sheet-dependent parameters (values listed in De Boer et al., 2010) that determine the influence of 
annual mean temperature $(\Delta T)$ and surface height $(\Delta Z)$ perturbations with respect to present day. Present-day isotopic contents $\left(\delta^{18} \mathrm{O}_{\mathrm{PD}}\right)$ match the modelled values of an earlier study by Lhomme et al. (2005). The modelled benthic $\delta^{18} \mathrm{O}$ values follow from

$\delta^{18} \mathrm{O}=\left[\delta^{18} \mathrm{O}_{\mathrm{b}}\right]_{\mathrm{PD}}-\frac{\overline{\delta^{18} \mathrm{O}_{\mathrm{i}}} V_{\mathrm{i}}}{V_{\mathrm{o}}}+\left[\frac{\overline{\delta^{18} \mathrm{O}_{\mathrm{i}}} V_{\mathrm{i}}}{V_{\mathrm{o}}}\right]_{\mathrm{PD}}+\gamma \Delta T_{\mathrm{o}}$,

where $\left[\delta^{18} \mathrm{O}_{\mathrm{b}}\right]_{\mathrm{PD}}$ is the observed present-day value of benthic $\delta^{18} \mathrm{O}$, and $V_{\mathrm{o}}$ and $V_{\mathrm{i}}$ are the ocean and land ice volume. The final term on the right-hand side quantifies the influence of deep sea temperature change with respect to present day $\left(\Delta T_{\mathrm{o}}\right)$. The gain factor $\gamma$ is set to $0.28 \% \mathrm{o} \mathrm{K}^{-1}$, taken from a paleotemperature equation (Duplessy et al., 2002). The coupled model is forced by insolation data (Laskar et al., 2004) and an inverse routine, which yields $\mathrm{CO}_{2}$ concentrations from the difference between the modelled benthic $\delta^{18} \mathrm{O}$ value and an observed value an output timestep later (Stap et al., 2016a):

$\mathrm{CO}_{2}=\overline{\mathrm{CO}_{2}} \times \exp \left[c \times\left\{\delta^{18} \mathrm{O}(t)-\delta^{18} \mathrm{O}_{\mathrm{obs}}(t+0.5 \mathrm{kyr})\right\}\right]$,

where $\overline{\mathrm{CO}_{2}}$ is the mean $\mathrm{CO}_{2}$ concentration of the preceding $15 \mathrm{kyr}$, and $c$ is a strength-determining parameter (Stap et al., 2016a). For the observed benthic $\delta^{18} \mathrm{O}$ values we use stacked records (Lisiecki and Raymo, 2005; Zachos et al., 2008), which effectively serve as model input. The radiative forcing anomaly with respect to present day is multiplied by a factor of 1.3 to account for non- $\mathrm{CO}_{2}$ greenhouse gases. This factor is based on analysis of $\mathrm{CH}_{4}$ and $\mathrm{N}_{2} \mathrm{O}$ records over the past $800 \mathrm{kyr}$ (see Stap et al., 2014) and used to account for the lack of knowledge on non- $\mathrm{CO}_{2}$ greenhouse gases prior to that period. An increase or decrease in the relative contribution of non- $\mathrm{CO}_{2}$ would need an opposing change in $\mathrm{CO}_{2}$. The result of the coupled model consists of mutually consistent records of benthic $\delta^{18} \mathrm{O}$, atmospheric $\mathrm{CO}_{2}$, temperature, and ice-volume-equivalent sea level.

\section{Results and discussion I: long-term transient simulations}

\subsection{Hysteresis}

We perform two model runs, one over the past $38 \mathrm{Myr}$ (this run is called " $38 \mathrm{Myr}$ "), and one over the past $5 \mathrm{Myr}$ (this run is called " $5 \mathrm{Myr}$ "). The $38 \mathrm{Myr}$ run uses the stacked benthic $\delta^{18} \mathrm{O}$ record of Zachos et al. (2008) as forcing. As a spin-up the model was initialised with a $1500 \mathrm{ppm} \mathrm{CO}_{2}$ concentration for $50 \mathrm{kyr}$ and thereafter run for $2 \mathrm{Myr}$ between 40 and $38 \mathrm{Myr}$ ago using the inverse routine. This run is an extension of the reference run used in Stap et al. (2016b) to include the past 10 Myr. The record of Lisiecki and Raymo (2005) was used to force the $5 \mathrm{Myr}$ run after initialising the model for $100 \mathrm{kyr}$ with $430 \mathrm{ppmCO}_{2}$. This run served as a reference run before in Stap et al. (2016a). When we compare the
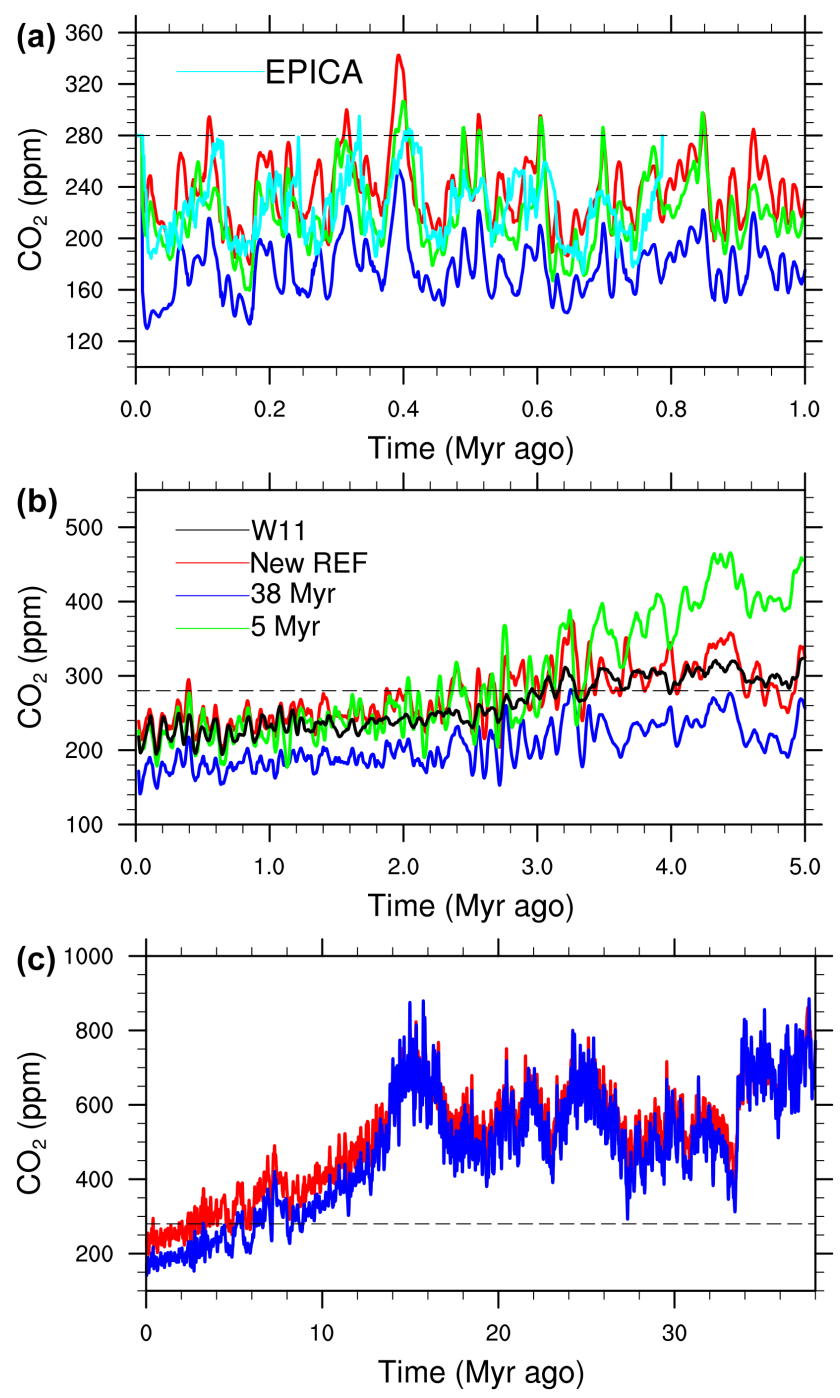

Figure 2. Atmospheric $\mathrm{CO}_{2}$ over the past $1 \mathrm{Myr}$ (a), the past $5 \mathrm{Myr}$ (b), and the past $38 \mathrm{Myr}$ (c). The $5 \mathrm{Myr}$ run from Stap et al. (2016a) (green), the extended $38 \mathrm{Myr}$ run from Stap et al. (2016b) (blue), the new reference run with altered cloud optical thickness (red), the hybrid proxy data-model reconstruction by Van de Wal et al. (2011) (W11; black), and the ice core record are shown (Petit et al., 1999; Siegenthaler et al., 2005; Lüthi et al., 2008) (EPICA; cyan). The ice cores stem from Antarctica, and the oldest values are from the EPICA Dome $\mathrm{C}$ core. Mind the differing $y$ scales. The dashed line shows the pre-industrial value $(280 \mathrm{ppm})$. In panel (a) we do not show 40 kyr averages, but the 1 kyr output of the model.

final $5 \mathrm{Myr}$ of our $38 \mathrm{Myr}$ simulation to our $5 \mathrm{Myr}$ simulation, we notice that the $38 \mathrm{Myr}$ simulation shows much lower $\mathrm{CO}_{2}$ concentrations (Fig. 2b, green and blue lines). These contradicting results cannot be explained by the use of different forcing records - Zachos et al. (2008) for $38 \mathrm{Myr}$ as opposed to Lisiecki and Raymo (2005) for $5 \mathrm{Myr}$ - as these show similar values during this time $(0.02 \%$ average difference, not shown). To explore the difference, we additionally 

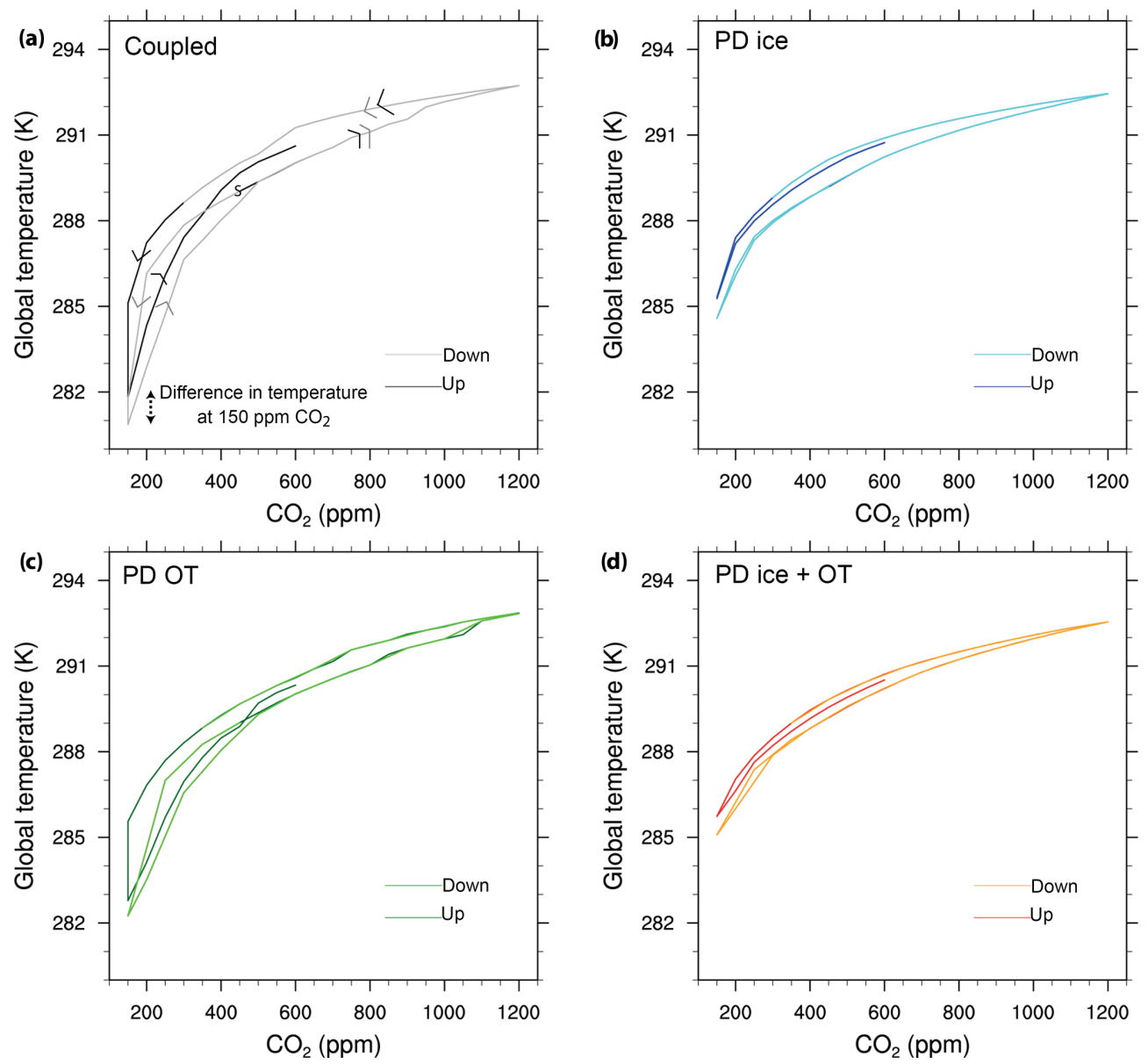

Figure 3. Relation between $\mathrm{CO}_{2}$ and global temperature in the equilibrium runs. In panel (a), the fully coupled model output is shown. The starting point of the simulation at $450 \mathrm{ppmCO}_{2}$ is marked by an $\mathrm{S}$, and the consequent evolution for both runs is marked by coloured arrows. The black line shows the up run in which $\mathrm{CO}_{2}$ is increased first, and the grey line shows the down run in which $\mathrm{CO}_{2}$ is decreased first. At high $\mathrm{CO}_{2}$ levels, the black line is overlaid by the grey line. (b) The output with uncoupled ice (blue and cyan), (c) with uncoupled ocean overturning strength (dark green and green), and (d) with both these factors uncoupled (red and orange). The darker colours (blue, dark green, red) show the up runs, and the lighter colours (cyan, green, orange) show the down runs. The starting point and evolution are the same as in panel (a).

conduct four pairs of experiments with the model in forward mode. In forward mode, we do not use the inverse routine but force the model by $\mathrm{CO}_{2}$ scenarios designed a priori. We initialise the model using a $450 \mathrm{ppmCO}_{2}$ concentration, no land ice, and glacio-isostatically relaxed present-day topography. We force the model by changing the $\mathrm{CO}_{2}$ input in steps of $50 \mathrm{ppm}$ every $50 \mathrm{kyr}$. In one set of experiments (named "up"), the $\mathrm{CO}_{2}$ is first raised from 450 to $1200 \mathrm{ppm}$, then lowered to $150 \mathrm{ppm}$, and increased again to $600 \mathrm{ppm}$. In the other set (named "down"), the $\mathrm{CO}_{2}$ is initially dropped from 450 to $150 \mathrm{ppm}$, then raised to $1200 \mathrm{ppm}$, and ultimately decreased again to $300 \mathrm{ppm}$. Insolation is kept at PD level throughout all these equilibrium experiments.

Starting at $450 \mathrm{ppmCO}_{2}$, the up and down runs show the same initial global temperature (Fig. 3a). However, in the down run in which the $\mathrm{CO}_{2}$ progresses stepwise down- ward first and then upward, the global temperatures at low $(<450 \mathrm{ppm}) \mathrm{CO}_{2}$ values are approximately a degree lower than those in the up run in which $\mathrm{CO}_{2}$ is first raised and then lowered. When the down run is integrated over another $\mathrm{CO}_{2}$ cycle, it shows the same global temperatures as the up run (not shown). This means that once the coupled model has experienced high $\mathrm{CO}_{2}$ values during its run, as is the case in the $38 \mathrm{Myr}$ run but not in the $5 \mathrm{Myr}$ run, the climates at lower $\mathrm{CO}_{2}$ values are warmer. This has important consequences for the simulated $\mathrm{CO}_{2}$ concentrations as they have to decline further to obtain similar temperatures, which is what happens in the transient $38 \mathrm{Myr}$ simulation forced by the inverse routine. The different branches in Fig. 3 are stable equilibria of the model. The model behaviour does not depend on the forcing rate: using $50 \mathrm{ppm} / 100 \mathrm{kyr}, 50 \mathrm{ppm} / 50 \mathrm{kyr}$, or $100 \mathrm{ppm} / 100 \mathrm{kyr}$ leads to the same results. This behaviour 
is a form of hysteresis as results depend on previous conditions of the model. The question now arises of what the cause of this hysteresis is. The global temperature difference between the up and down run is $0.94 \mathrm{~K}$ at $150 \mathrm{ppmCO}_{2}$. The difference is generally larger at higher than at lower latitudes, peaking at $60^{\circ} \mathrm{S}$ and $80^{\circ} \mathrm{N}$ (Fig. 4, red line). When the ice sheet model is uncoupled and the climate model is directly forced in the same manner but using PD ice sheets, the globally averaged temperature difference reduces to $0.69 \mathrm{~K}$ (Fig. 3b). Keeping the ocean overturning strength, a known source of hysteresis in other models (e.g. Zhang et al., 2014), fixed at PD also leads to a small reduction; the difference becomes $0.73 \mathrm{~K}$ (Fig. 3c). The combined effect of uncoupled ice and ocean overturning strength is still not sufficient to eliminate the hysteresis (Fig. 3d). Even when sea ice and snow cover are additionally kept constant, a small hysteresis $(0.11 \mathrm{~K}$ difference at $150 \mathrm{ppm})$ is present. This difference is now more uniformly spread over the globe, albeit slightly larger in the Southern Hemisphere than in the Northern Hemisphere (Fig. 4, blue line). Having ruled out albedo and ocean overturning strength, which only act to enhance it, the source of the hysteresis is most likely the temperature dependency of atmospheric transparency to short- and longwave radiation in the energy balance calculations (Bintanja, 1996). Unfortunately, disabling this dependency in the energy balance calculations leads to numerical instability, causing the model to crash shortly after initiation. However, its influence is suggested by the model converging to a smaller steady-state energy imbalance at the top of the atmosphere when the model has previously experienced high $\mathrm{CO}_{2}$ values. This is the case in both the fully coupled run (Supplement Fig. S1a) and the run in which surface albedo and ocean overturning strength are kept fixed (Supplement Fig. S1b). An energy imbalance at the top of the atmosphere when the atmospheric and oceanic temperatures have equilibrated means there is an energy leak. When this energy leak is positive, the outgoing radiation and therefore the radiative temperature of the Earth are underestimated. For steady-state PI conditions, most general circulation models (GCMs) show positive energy imbalances, typically below $2 \mathrm{Wm}^{-2}$ (Lucarini and Ragone, 2011). In our model, more energy is lost at higher $\mathrm{CO}_{2}$ concentrations, meaning the model simulates increasingly too-cold temperatures towards warmer climates. Therefore, the climate sensitivity is underestimated. However, the energy leak remains relatively small: 0 to $4.6 \mathrm{Wm}^{-2}$ globally averaged for $\mathrm{CO}_{2}$ values between 150 and $1200 \mathrm{ppm}$ (Supplement Fig. S1a). In the inverse mode runs, the energy imbalance is indeed also different: the energy imbalance is smaller in the $38 \mathrm{Myr}$ run than in the $5 \mathrm{Myr}$ run (Supplement Fig. S2, blue and green lines), indicating that the modelled climate states in these runs are in different branches of the curve shown in the Supplement Fig. S1. Although the difference in energy imbalance is small between the different branches, it evidently has important implications for the simulated $\mathrm{CO}_{2}$ in inverse mode.

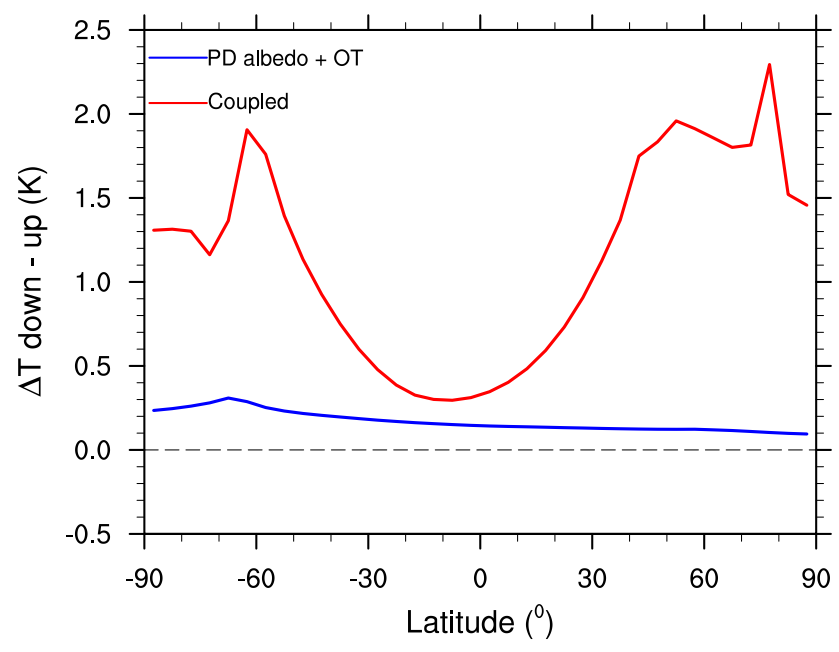

Figure 4. Atmospheric temperature difference at $150 \mathrm{ppm}$ between the equilibrium runs (down - up) using the fully coupled set-up (red) and using fixed PD surface albedo and ocean overturning strength (blue).

\subsection{Retuning: new reference simulation}

Originally, the $5 \mathrm{Myr}$ run was calibrated to an Antarctic ice core proxy $\mathrm{CO}_{2}$ record (Petit et al., 1999; Siegenthaler et al., 2005; Lüthi et al., 2008) over the past $800 \mathrm{kyr}$ (Stap et al., 2016a). It shows negligible bias $(-3.9 \mathrm{ppm})$ to that record. As a consequence of the hysteresis described in Sect. 3.1, the $38 \mathrm{Myr}$ run shows much lower values than this proxy record with a -47.7 ppm bias (Fig. 2a; mind that we show 1 kyr values instead of $40 \mathrm{kyr}$ averages). The simulated $\mathrm{CO}_{2}$ over the past $5 \mathrm{Myr}$ in the $38 \mathrm{Myr}$ run is also much lower than the hybrid proxy data-model reconstruction by Van de Wal et al. (2011) (Fig. 2b, black line). Therefore, we deduce that the $\mathrm{CO}_{2}$ record of the $38 \mathrm{Myr}$ run is not realistic over this period. To regain agreement with the ice core record, which we judge to be essential for a transient paleoclimate simulation, we define a new reference run in this study (new REF). In this new reference run we increase the cloud optical thickness parameter $\tau_{\mathrm{cl}}$ from 3.11 to 3.41 . We opt to alter this parameter because it was already used as a tuning parameter in the original climate model (Bintanja, 1997) and in the ice sheet-climate model coupling (Stap et al., 2014). Both values are physically plausible. Increasing $\tau_{\mathrm{cl}}$ will lower the temperatures calculated by the climate model, such that for the same benthic $\delta^{18} \mathrm{O}$ higher simulated $\mathrm{CO}_{2}$ levels are obtained, which is in better agreement with the ice core record. However, this will also raise the threshold $\mathrm{CO}_{2}$ level for the inception of the East Antarctic ice sheet (EAIS). By increasing the ablation threshold parameter $C_{\mathrm{abl}}$ in the insolation-temperature-melt calculation (Eq. 2) of the EAIS (from -30 to -10), this ice sheet glaciates at lower temperatures and therefore at lower $\mathrm{CO}_{2}$ concentrations. This parameter was used in Stap et al. (2014) to match the $\mathrm{CO}_{2}$ inception point for Antarctic glacial 
inception to the one found by DeConto and Pollard (2003) $(\sim 780 \mathrm{ppm})$ and is also poorly constrained. Changing this parameter compensates for the unintended $\mathrm{CO}_{2}$ threshold increase. We force the model in the same way as the earlier $38 \mathrm{Myr}$ run over the past $38 \mathrm{Myr}$ using the stacked benthic record of Zachos et al. (2008) as forcing.

The $\mathrm{CO}_{2}$ concentrations of the new reference simulation are shown in Fig. 2 by red lines. The simulated $\mathrm{CO}_{2}$ levels right before the Eocene-Oligocene transition (EOT; $\sim 33.9 \mathrm{Myr}$ ago) and at the mid-Miocene climatic optimum (MMCO; 17 to $15 \mathrm{Myr}$ ago) are similarly high at around 650 to $750 \mathrm{ppm}$, as in the earlier $38 \mathrm{Myr}$ simulation (Fig. 2c). In the time between these events, $\mathrm{CO}_{2}$ in the new reference run is modestly higher, up to $100 \mathrm{ppm}$. This is because the deep sea temperatures are lower at the same $\mathrm{CO}_{2}$ and therefore contribute less to the $\delta^{18} \mathrm{O}$ anomaly with respect to present day. Compensating for the lower deep sea temperatures, higher $\mathrm{CO}_{2}$ increases the $\delta^{18} \mathrm{O}$ anomaly by increasing both deep sea temperature and the contribution of ice volume and hence raising sea levels (not shown). After the MMCO when the EAIS has stabilised to near-PD size, the new reference simulation shows higher $\mathrm{CO}_{2}$ values than the earlier $38 \mathrm{Myr}$ simulation. Over the past million years, the new reference simulation (Fig. 2a, red line) agrees much better with the $5 \mathrm{Myr}$ run (Fig. 2a, green line) and with the ice core $\mathrm{CO}_{2}$ record (Fig. 2a, cyan line); the bias with respect to this proxy record is reduced to $13.6 \mathrm{ppm}$. Even after recalibration, the simulated new reference $\mathrm{CO}_{2}$ remains lower than in the $5 \mathrm{Myr}$ run during the Pliocene and early Pleistocene (Fig. 2b, green line) as a consequence of the hysteresis. Although it is more variable than the reconstruction based on a constant Earth system sensitivity (ESS) by Van de Wal et al. (2011) (Fig. 2b, black line), the long-term means are now similar. It remains debatable whether the shorter $5 \mathrm{Myr}$ run or the new reference simulation is the most veracious over the past $5 \mathrm{Myr}$. On the one hand, the long simulation carries a longer memory, which would be closer to the state of the actual climate system. Furthermore, the energy imbalance at the top of the atmosphere is not affected significantly by retuning the model and remains lower in this simulation than in the $5 \mathrm{Myr}$ run (Supplement Fig. S2, red line). On the other hand, it is uncertain how accurately our climate model simulates very warm climates; the climate model is designed and tested for PD and LGM climates (Bintanja and Oerlemans, 1996). This argument favours the shorter $5 \mathrm{Myr}$ run as the more trustworthy result, implying that $\mathrm{CO}_{2}$ levels over the last $5 \mathrm{Myr}$ may have been up to $470 \mathrm{ppm}$.

\subsection{Comparison to proxy $\mathrm{CO}_{2}$ data}

A comprehensive quantitative comparison between our $\mathrm{CO}_{2}$ simulation and proxy data is hindered by scarcity and intermittency of data records. Nevertheless, in Fig. 5 we show the new reference $\mathrm{CO}_{2}$ results together with proxy data over three periods for which data are relatively abundant: the Late
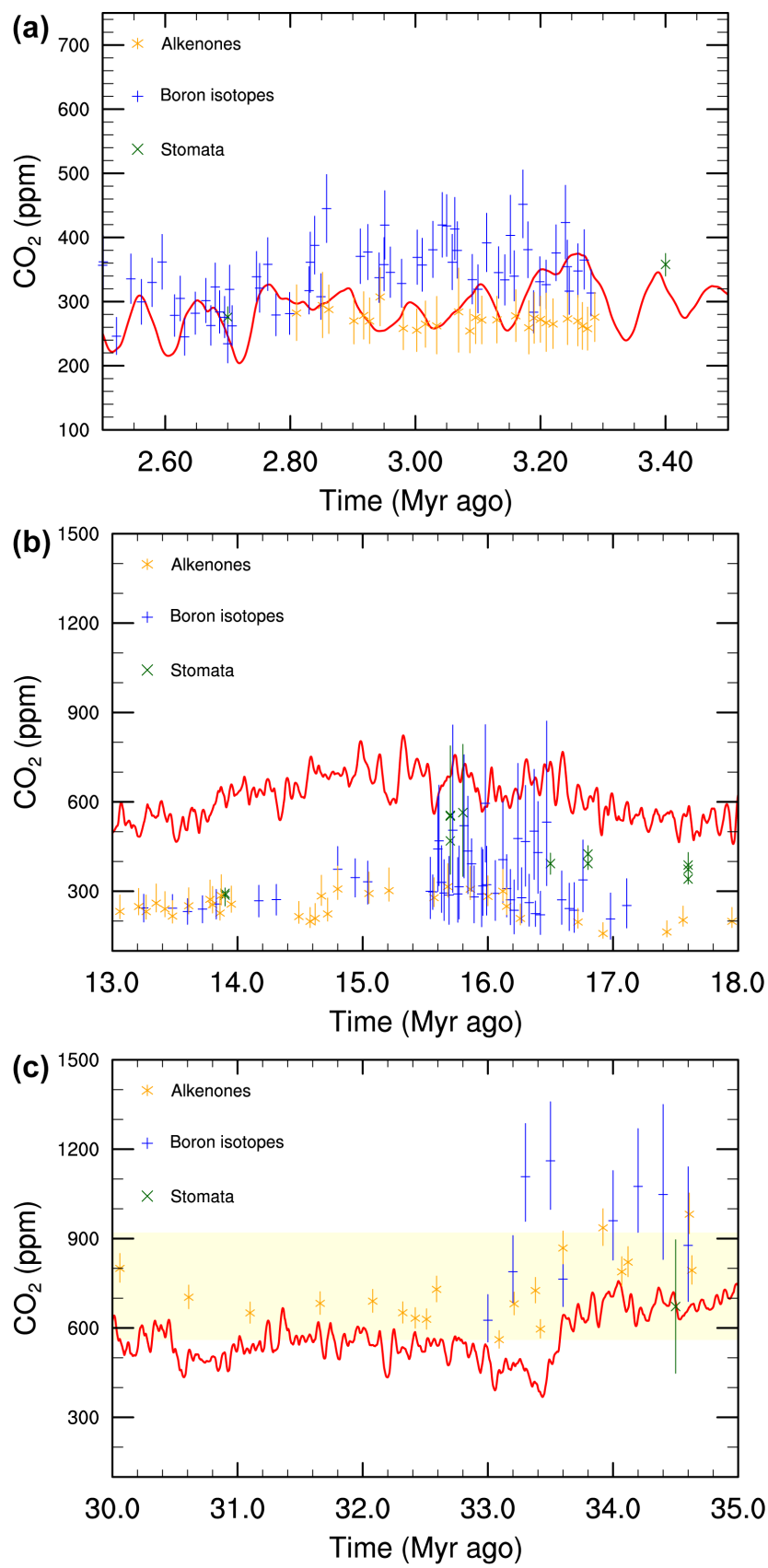

Figure 5. Simulated $\mathrm{CO}_{2}$ concentrations of the new reference run (red line) for the (a) Late Pliocene (3.5 to 2.5 Myr ago), (b) Middle Miocene (18 to $13 \mathrm{Myr}$ ago), and (b) Early Oligocene (35 to $30 \mathrm{Myr}$ ago); 40 kyr running averages are shown. Proxy data reconstructions based on alkenones (Pagani et al., 1999, 2011; Badger et al., 2013) are indicated by orange asterisks. Boron-isotope-based data (Pearson et al., 2009; Foster et al., 2012; Greenop et al., 2014; MartínezBotí et al., 2015) are indicated by blue plus symbols. Stomata-based data (Van der Burgh et al., 1993; Kürschner, 1996; Kürschner et al., 2008; Retallack, 2009) are indicated by green crosses. Yellow shading indicates the range of Antarctic glaciation values found by Gasson et al. (2014) 
Pliocene ( 3.5 to $2.5 \mathrm{Myr}$ ago), the Middle Miocene (18 to $13 \mathrm{Myr}$ ago), and the Early Oligocene (35 to $30 \mathrm{Myr}$ ago). The data are based on three important proxies (see also Beerling and Royer, 2011): alkenones (Pagani et al., 1999, 2011; Badger et al., 2013), boron isotopes (Pearson et al., 2009; Foster et al., 2012; Greenop et al., 2014; Martínez-Botí et al., 2015), and stomata (Van der Burgh et al., 1993; Kürschner, 1996; Kürschner et al., 2008; Retallack, 2009). During the Late Pliocene, the simulated $\mathrm{CO}_{2}$ is more variable than the alkenone data from Badger et al. (2013) (Fig. 5a). This discrepancy between our simulation and the alkenone proxy (Pagani et al., 1999) is persistent throughout the Miocene (not shown). The variability in our simulation is more in line with the boron isotope proxy (Martínez-Botí et al., 2015), although our simulated $\mathrm{CO}_{2}$ values are lower between 3.2 and 2.8 Myr ago, closer to the alkenone estimates of Badger et al. (2013). Modelling studies with GCMs generally use higher values for the Pliocene, for example $400 \mathrm{ppm}$ in the forthcoming PlioMIP2 experiments (Haywood et al., 2016). Comparison to the boron isotope proxy over the Miocene is hampered by lack of data. It would be interesting to know if this proxy also shows larger variability during that epoch. During the Middle Miocene, our simulated $\mathrm{CO}_{2}$ is considerably higher than all proxy data records (Fig. 5b). Contrarily, during the Early Oligocene, it is a little bit lower (Fig. 5c). As mentioned in Sect. 3.2, the $\mathrm{CO}_{2}$ inception point for Antarctic glacial inception was tuned to the one found by DeConto and Pollard (2003) ( $780 \mathrm{ppm})$. It is therefore in agreement with the range of Antarctic glaciation values found by Gasson et al. (2014) using combinations of an ice dynamical model coupled to seven climate models (Fig. 5c, yellow shading). Using a different tuning, our Middle Miocene values are closer to the observations, but then the Early Oligocene values are also much lower (see Stap et al., 2016b, for an analysis). In short, we are not able to simulate a difference in $\mathrm{CO}_{2}$ between right before the Eocene-Oligocene transition and during the Middle Miocene climatic optimum. As our $\mathrm{CO}_{2}$ simulation is obtained using benthic $\delta^{18} \mathrm{O}$, this could indicate a discrepancy between the $\delta^{18} \mathrm{O}$ and $\mathrm{CO}_{2}$ proxies. More likely, however, it is in the largest part due to processes missing in our model set-up. Over the course of millions of years, tectonics, erosion, and vegetation have led to topography and albedo changes that affect the climate system. Contrary to the findings of Foster and Rohling (2013), these geological processes may have had a significant impact on the relation between $\mathrm{CO}_{2}$, sea level, and temperature (Gasson et al., 2016). Indeed, in Stap et al. (2016b) we showed that in our model erosion could lead to a changing relation between $\mathrm{CO}_{2}$ and ice volume over time, bringing $\delta^{18} \mathrm{O}$ and $\mathrm{CO}_{2}$ in line with other proxy indicators arguing for the importance of erosion. Also, we use a uniform lapse rate correction of $6.5 \mathrm{~K}$ for height changes in our model, which is a potentially important simplification (Gasson et al., 2014; Botsyun et al., 2016). In the future, our simulation can be improved by including these processes. For now, with this limitation in mind, we will fo- cus on the long-term interaction between ice sheets and the climate in our model.

\section{Results and discussion II: ice sheet-climate interaction}

Figure 6 shows the main results of the new reference run: benthic $\delta^{18} \mathrm{O}$, atmospheric $\mathrm{CO}_{2}$, ice-volume-equivalent sea level, and global temperature. The latter two are largely similar to De Boer et al. $(2010,2012)$ in which comparisons to proxy data and other modelling studies can also be found. For example, they showed satisfactory agreement with a sea level curve derived from Red Sea sediments (Rohling et al., 2009) and a $\mathrm{Mg} / \mathrm{Ca}$ proxy data deep sea temperature record (Sosdian and Rosenthal, 2009). In our model, the relation between temperature and ice volume can roughly be divided into three regimes (see also De Boer et al., 2010; Van de Wal et al., 2011): (1) at low $\mathrm{CO}_{2}$ values, strong ice volume variability due to dynamic Northern Hemisphere ice sheets; (2) at intermediate $\mathrm{CO}_{2}$ values, weaker variability; (3) and at high $\mathrm{CO}_{2}$ values, strong variability due to a dynamic Antarctic ice sheet. This constitutes a sigmoidal temperature-sea level relation. The data analysis results of Gasson et al. (2012) show a similar shape but with higher deep sea temperature anomalies during the warmer-than-PI climates. This was also the case in an earlier study using the same ice sheet model but with parameterised deep sea temperatures (De Boer et al., 2010). The trend we model in sea surface temperatures is also lower than what is suggested by proxy data (Herbert et al., 2016) (not shown). The modelled relation between logarithmic $\mathrm{CO}_{2}$ and sea level is also sigmoidal. This is in very good agreement with the results from Foster and Rohling (2013), who derived a functional relation between these quantities from a geological data perspective (Fig. 7). However, sea level during the stable middle regime is lower in our case. This is coherent with the modelling results of Gasson (2013) (Supplement Fig. S3). Possibly, recent advances in ice sheet modelling (Pollard et al., 2015) can explain (part of) this difference between models and data. Furthermore, our highest $\mathrm{CO}_{2}$ levels are slightly lower than the data show. The modelled $\mathrm{CO}_{2}$ threshold for Antarctic glaciation is highly dependent on the mass balance parameterisation (Stap et al., 2016b; Gasson, 2013), the climate model used (Gasson et al., 2014), and the Antarctic topography (Stap et al., 2016b; Gasson et al., 2014). In our case, this threshold is distinctly higher than that for land ice in the Northern Hemisphere. This is mainly a consequence of the higher latitude of the Antarctic continent and in line with earlier findings (DeConto et al., 2008).

Now, we will investigate the influence of ice sheet-climate interaction on polar amplification and Earth system sensitivity (ESS). ESS is defined as the global temperature response to a radiative forcing caused by changing $\mathrm{CO}_{2}$, taking into account all climate feedbacks (PALAEOSENS Project Mem- 


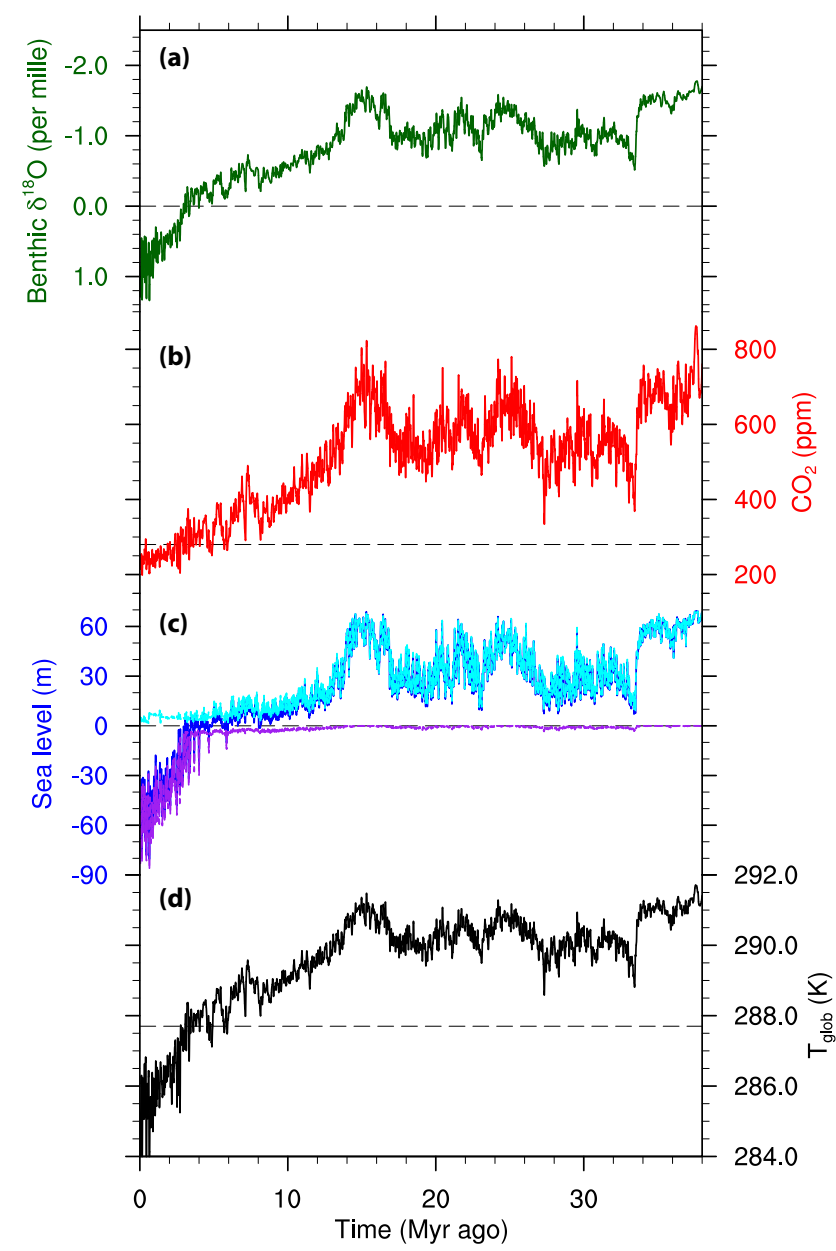

Figure 6. Results of the new reference run: (a) benthic $\delta^{18} \mathrm{O}$, (b) atmospheric $\mathrm{CO}_{2}$, (c) ice-volume-equivalent sea level in metres above present day (blue), and contributions from the Northern Hemisphere (purple) and Antarctic ice sheets (cyan). (d) Global mean temperature $\left(T_{\text {glob }}\right) ; 40$ kyr running averages are shown. Dotted lines represent pre-industrial (PI) values.

bers, 2012). This radiative forcing by $\mathrm{CO}_{2}$ is proportional to the logarithmic change in $\mathrm{CO}_{2}$ (Myhre et al., 1998). In Fig. 8 (red dots), we therefore show the relation between global temperature anomalies from pre-industrial (PI) and the logarithm of $\mathrm{CO}_{2}$ divided by a reference PI value of $280 \mathrm{ppm}$ in our new reference run. Evidently, this relation is not constant, as in warm climates the global temperature increase for a given $\mathrm{CO}_{2}$ increase is less strong. The slope of a least squares linear regression shows a value of $10.6 \mathrm{~K}$ for $\ln \left(\mathrm{CO}_{2} / \mathrm{CO}_{2, \text { ref }}\right)$ values below $0\left(\mathrm{CO}_{2}<280 \mathrm{ppm}\right.$ : coldest climates) and $3.7 \mathrm{~K}$ for values above $0.69\left(\mathrm{CO}_{2}>560 \mathrm{ppm}\right.$ : warmest climates), a reduction of $65 \%$. These values are equivalent to 7.3 and $2.6 \mathrm{~K}$ per $\mathrm{CO}_{2}$ doubling respectively. Hence, ESS is not constant, in contrast with the implicit assumption in Van de Wal et al. (2011). In fact, in our model ESS is stronger at lower $\mathrm{CO}_{2}$. This is similar to the find-

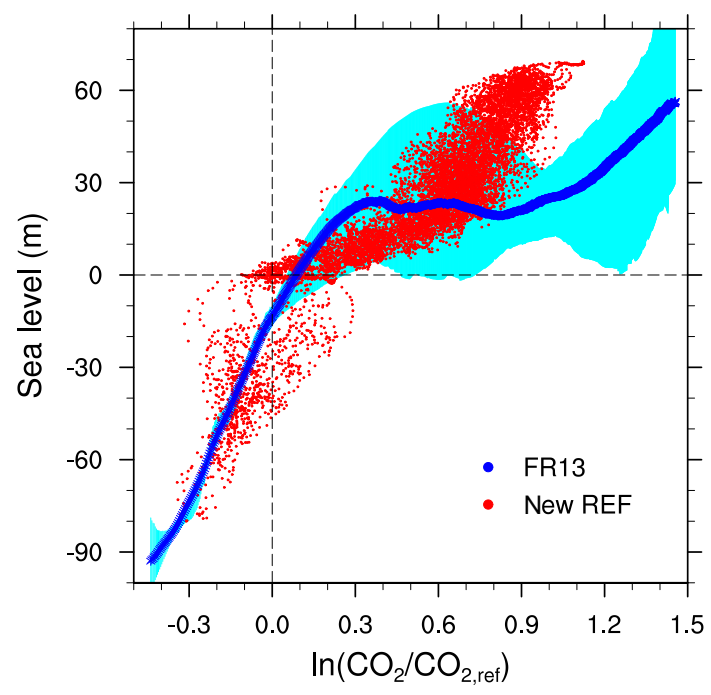

Figure 7. Relation between the logarithm of $\mathrm{CO}_{2}$ divided by the PI value of $280 \mathrm{ppm}$ and ice-volume-equivalent sea level anomalies with respect to PI for the reference simulation (red dots) compared to the median case of the probabilistic data analysis in Foster and Rohling (2013) (FR13, blue dots) with their $95 \%$ uncertainty range in cyan.

ings of Hansen et al. (2013), who performed $\mathrm{CO}_{2}$ doubling experiments using the simplified atmosphere-ocean model of Russell et al. (1995). However, their ESS decrease is less strong, as it drops from $\sim 6$ per $\mathrm{CO}_{2}$ doubling from 155 to $310 \mathrm{ppmCO}_{2}$ to $\sim 5.5 \mathrm{~K}$ from 620 to $1240 \mathrm{ppm}$ (see their Fig. 8b). They eventually also find increased sensitivity again at very high $\mathrm{CO}_{2}$ levels ( 2480 to $9920 \mathrm{ppm}$ ), which is outside the range we simulate during our time span.

In our ice uncoupled run, the slope of the relation between $\mathrm{CO}_{2}$ and global temperature is reduced by only $46 \%$ from 5.6 to $3.0 \mathrm{~K}$ going from the coldest to the warmest $\ln \left(\mathrm{CO}_{2} / \mathrm{CO}_{2, \text { ref }}\right)$ regime (Fig. 8, blue dots). In this case, the standard error of a linear regression through all data points is reduced by $58 \%$ with respect to the fully coupled run, from 0.0050 to $0.0021 \mathrm{~K}$. The fact that the relation between $\ln \left(\mathrm{CO}_{2} / \mathrm{CO}_{2}\right.$,ref $)$ and global temperature is better approximated by a linear fit when land ice is uncoupled means the $\log \left(\mathrm{CO}_{2}\right)-T$ relation is more linear. Hence, climate sensitivity is more constant. However, even when ice sheets are kept at PD level, the relation between logarithmic $\mathrm{CO}_{2}$ and global temperature shows a declining slope (Fig. 8, blue dots). Therefore, decreased sensitivity at higher $\mathrm{CO}_{2}$ is not only determined by reduced ice volume variability. This finding may be compared to the hybrid data-model results for climate sensitivity of Köhler et al. (2015) and to the modelled climate sensitivity of Friedrich et al. (2016). Köhler et al. (2015) investigated the relation between the radiative forcing of proxy data $\mathrm{CO}_{2}$ (Petit et al., 1999; Siegenthaler et al., 2005; Lüthi et al., 2008; Hönisch et al., 2009), which is linearly related to logarithmic $\mathrm{CO}_{2}$ (Myhre et al., 1998), and 


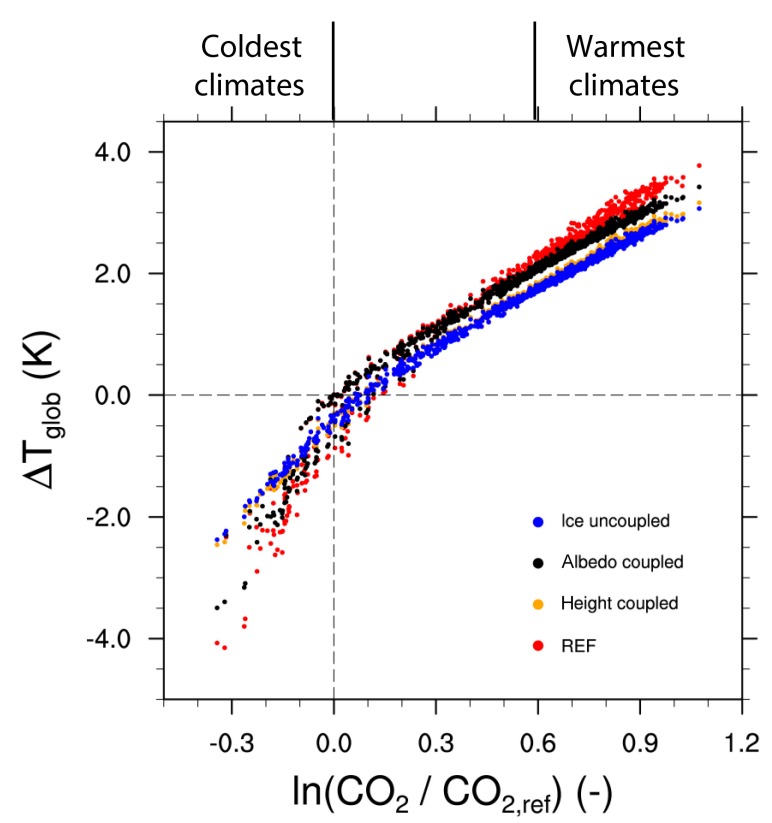

Figure 8. Relation between the logarithm of $\mathrm{CO}_{2}$ divided by the PI value of $280 \mathrm{ppm}$ and global temperature anomalies with respect to PI (of the reference run) for the reference simulation (red dots), the simulation with uncoupled ice (blue dots), and the simulation with only surface height (orange dots) or albedo (black dots) coupled.

modelled global temperature (De Boer et al., 2014, scaled). Friedrich et al. (2016) forced the intermediate complexity climate model LOVECLIM over the past $800 \mathrm{kyr}$ using the ice core record (Petit et al., 1999; Siegenthaler et al., 2005; Lüthi et al., 2008) and a Northern Hemisphere ice sheet reconstruction (Ganopolski and Calov, 2011). The resulting climate sensitivity of these studies is opposite to ours, as they show increased climate sensitivity at higher $\mathrm{CO}_{2}$ concentrations. These studies, however, consider a smaller range of $\mathrm{CO}_{2}$. Furthermore, they calculate climate sensitivity in a different way. They do take into account ice volume variations, but compensate for their effect by adding their radiative forcing to the forcing induced by $\mathrm{CO}_{2}$ variations (see PALAEOSENS Project Members, 2012). Implicitly assumed in their approach is that these radiative forcings have the same effect on temperature, which may not generally be the case (Yoshimori et al., 2011). The difference between the results of our model and these studies could point to contrasting strengths of the fast feedbacks in the climate system, which is material for future investigation. Our findings are in agreement with Ritz et al. (2011), who used a two-dimensional energy balance climate model that showed an increase in climate sensitivity from $3.0 \mathrm{~K}$ per $\mathrm{CO}_{2}$ doubling at PI conditions to $4.3 \mathrm{~K}$ at LGM conditions.

The coldest global temperature anomaly in our results is amplified by $79 \%$ (factor of 1.79) if land ice changes are incorporated, by $50 \%$ if only albedo is coupled (Fig. 8, black dots), and by $4 \%$ if only surface height is coupled (Fig. 8 , orange dots). The warmest anomaly is only increased by $21 \%$ (factor of 1.21 ) when ice is coupled, by $9 \%$ when only albedo is coupled, and by $3 \%$ when only surface height is coupled. This means the surface-height-temperature feedback becomes relatively more important in warmer climates.

The influence of ice sheets on the climate is strongest in the region where they are situated, leading to increased polar amplification. This is demonstrated by the relations between global temperature and Northern Hemisphere $\left(40\right.$ to $80^{\circ} \mathrm{N}$; Fig. 9a) and Antarctic temperature (60 to $90^{\circ} \mathrm{S}$; Fig. 9b). In the Northern Hemisphere, the minimum local temperature with respect to PI is $-2.0 \mathrm{~K}$ in the uncoupled case and $-9.5 \mathrm{~K}$ in the run with fully coupled land ice. When only the albedo or surface height changes are coupled, the Northern Hemisphere temperature anomaly reaches -6.4 and $-2.8 \mathrm{~K}$ as low points respectively. Conversely, the amount of land ice lost in warmer climates is relatively small, as only the Greenland ice sheet ( $\sim 7 \mathrm{~m}$.s.l.e.) is left to melt. Consequently, the Northern Hemisphere temperature is then not affected much by not including land ice changes. The remaining polar amplification in the Northern Hemisphere is hence mostly caused by other factors, such as sea ice and snow cover variability. In the Southern Hemisphere, the lowest temperature is similar for the coupled and uncoupled simulations, although it is achieved at a higher global temperature in the uncoupled case. These Southern Hemisphere temperatures are similarly low because the Antarctic ice sheet grows relatively little in size towards colder-than-PI conditions (see also Stap et al., 2014). When Antarctica is allowed to melt in warm climates, however, the local temperature increase becomes much stronger: 11.6 instead of $5.9 \mathrm{~K}$ with respect to PI. In these conditions, we find that coupling albedo changes leads to a maximum Antarctic temperature anomaly of only $7.0 \mathrm{~K}$ (Fig. 9b, black dots). When only surface height changes are coupled, this anomaly reaches $7.4 \mathrm{~K}$ (Fig. 9b, orange dots). This result implies that albedo changes are relatively less important in Antarctica than in the high latitudes of the Northern Hemisphere. The reason is that the Antarctic continent remains snow covered throughout most of the year when the land ice retreats, which reduces the albedo change (see also Stap et al., 2016a). Since temperature changes are strongest in the Southern Hemisphere in warmer-than-PI climates, this explains the increased relative importance of the surfaceheight-temperature feedback on ESS in these climates. The different response of the northern and southern high latitudes to $\mathrm{CO}_{2}$ changes challenges the approach of De Boer et al. $(2010,2012)$, who reconstructed a single high-latitude temperature anomaly. Furthermore, their record cannot readily be translated to global conditions by a constant factor (as is done in e.g Martínez-Botí et al., 2015) because the conversion depends on the prevailing climate state. This problem with recalculating high-latitude values in terms of global mean changes also holds for other local proxy data like marine, terrestrial, or ice core records. 

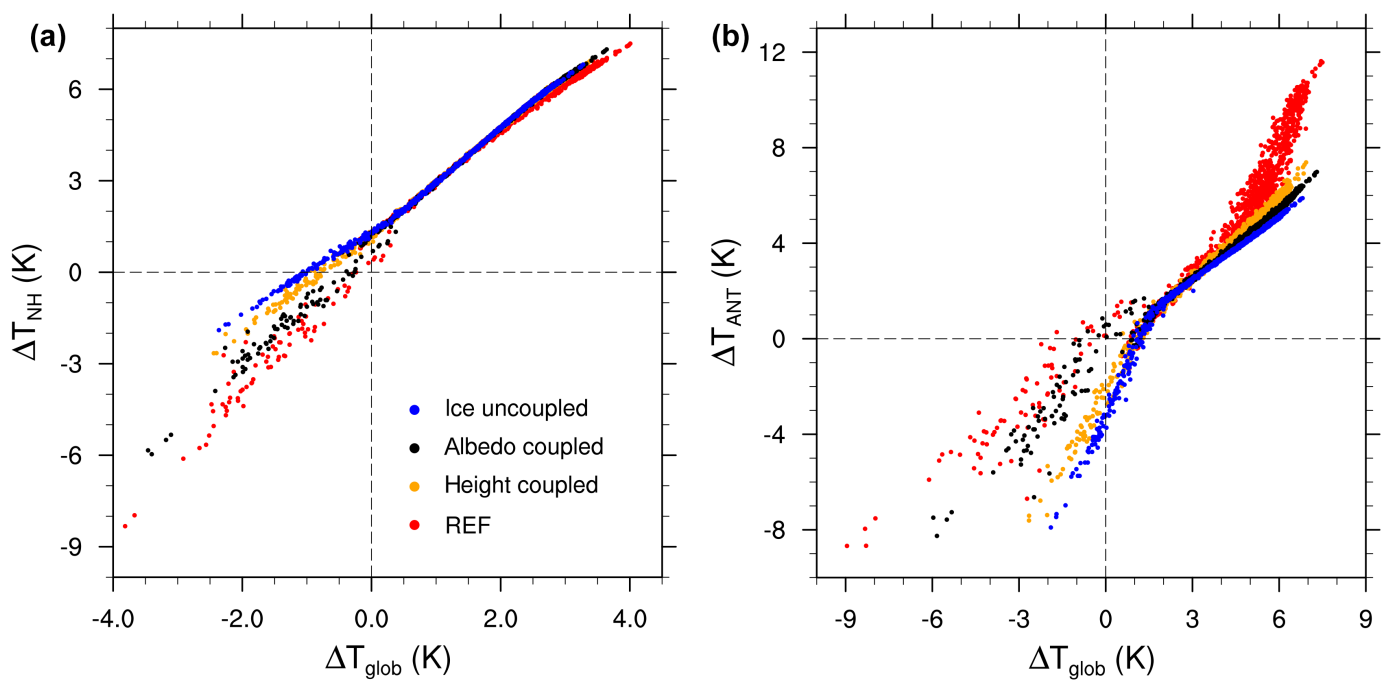

Figure 9. Relation between anomalies with respect to PI (of the reference run) of global temperature, (a) Northern Hemisphere temperature $\left(40\right.$ to $\left.80^{\circ} \mathrm{N}\right)$, and (b) Antarctic temperature $\left(60\right.$ to $90^{\circ} \mathrm{S}$ ) for the reference simulation (red dots), the simulation with uncoupled ice (blue dots), and the simulation with only surface height (orange dots) or albedo (black dots) coupled.

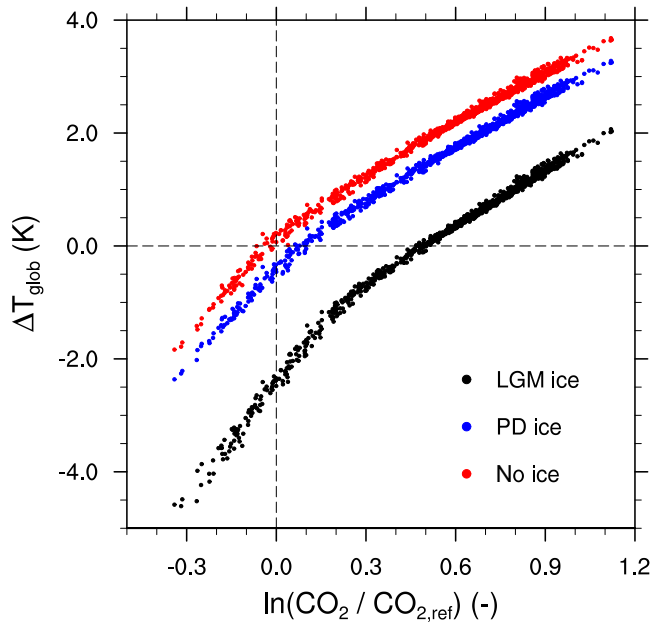

Figure 10. Relation between the logarithm of $\mathrm{CO}_{2}$ divided by the PI value of $280 \mathrm{ppm}$ and global temperature anomalies with respect to PI (of the reference run) for the simulation with ice kept at PD level (blue dots), at LGM level (black dots), and the simulation with all land ice removed (red dots).

Finally, we compare the relation between global temperature and logarithmic $\mathrm{CO}_{2}$ in three model runs with uncoupled ice (Fig. 10). In one run the ice sheets are kept at PD condition as before (now called PD ice, blue dots), in another one we use the LGM condition (LGM ice, black dots), and in the last one all ice is removed (no ice, red dots). Naturally, the more ice is present on Earth, the colder the climate becomes, so the LGM ice run is colder than the PD ice run, which in turn is colder than the no ice run. The difference between the PD ice and the no ice run is fairly uniform over the whole
$\mathrm{CO}_{2}$ range. The difference between the LGM ice and the no ice run, however, is larger in cold climates than in warm climates as it shrinks from $\sim 2.8$ to $\sim 1.6 \mathrm{~K}$. This is explained by the extra land ice in the LGM ice run cooling the climate and increasing the area on Earth covered by snow and sea ice. As a result of this area increase, the land surface has a higher albedo, which cools the climate further. In cold climates this effect is stronger because the snow- and sea-ice-covered area grows more towards the Equator where there is more incoming solar radiation. Consequently, the albedo increase is more effective as it leads to the absorption of more energy and thus to a stronger temperature decrease.

\section{Summary and conclusions}

We have presented mutually consistent transient simulations of atmospheric $\mathrm{CO}_{2}$ content, temperature, ice volume, and benthic $\delta^{18} \mathrm{O}$ over the past 38 million years. They were obtained using a coupling between a zonally averaged energy balance climate model and a one-dimensional ice sheet model. As forcing, we have used an inverse routine that yields atmospheric $\mathrm{CO}_{2}$ from an observed benthic $\delta^{18} \mathrm{O}$ record (Zachos et al., 2008). This allowed us to simulate periods before $800 \mathrm{kyr}$ ago, for which ice core records are not available and $\mathrm{CO}_{2}$ data are uncertain, scarce, and intermittent (Beerling and Royer, 2011). Focusing on long-term interactions between land ice and climate, we have taken a complementary approach to snapshot and short timescale simulations that have been published before (e.g. Langebroek et al., 2010; Ladant et al., 2014; Gasson et al., 2014; Pollard et al., 2015). Our coupled model results represent an improvement upon the work of De Boer et al. (2010), who used the same ice sheet model in stand-alone form to simu- 
late the past $40 \mathrm{Myr}$ (De Boer et al., 2010, 2012). The inclusion of a climate model has enabled us to simulate and force the different ice sheets with seasonal meridional temperature distributions instead of globally uniform perturbations to present-day climate with a fixed seasonal cycle. Nonetheless, we recognise that our coupled ice sheet model is relatively simple. It does not include ice shelf dynamics and sophisticated grounding line parameterisations (Pollard and DeConto, 2012; Pollard et al., 2015). The physics in our model are not detailed enough to simulate sub-millennial climate dynamics, which could have important consequences, for instance on tropical atmospheric circulation (Mulitza et al., 2008). However, more complex models, such as GCMs coupled to three-dimensional thermodynamic ice models, are not yet suitable to perform multi-million-year integrations because of limited computer power. Our results therefore serve as a reference to which the results of these more sophisticated models can be compared once they are achieved. This facilitates an analysis of which features appear in the full hierarchy of models and which are specific to more comprehensive models including more physics. Furthermore, by comparing our fully coupled simulation to model runs with the ice-albedo feedback, the surface-height-temperature feedback, or with both switched off, we have quantified the effect of ice sheet-climate interactions on Earth system sensitivity (ESS) and polar amplification on long timescales.

In our model, the results for $\mathrm{CO}_{2}$ concentrations lower than roughly $450 \mathrm{ppm}$ depend on the transient evolution of $\mathrm{CO}_{2}$. When the model has previously experienced high $\mathrm{CO}_{2}$ values during the run, temperatures are higher than when this is not the case. This hysteresis is persistent even in runs without any change in albedo due to snow, sea ice, or permanent land ice cover and without changes in ocean overturning strength. However, these factors do enhance it. The hysteresis is most likely a consequence of the temperature dependency of the energy balance calculations. This is suggested by the fact that the model converges to a different steady-state energy imbalance at the top of the atmosphere and therefore a different climate state depending on the history of the run. It is still unknown whether this behaviour is also exhibited by other models. We therefore suggest that in the future, climate models should be tested for this behaviour by confronting them with high $\mathrm{CO}_{2}$ values before simulating cooler climates. In our case, it leads to unrealistically low simulated $\mathrm{CO}_{2}$ values over roughly the past $13 \mathrm{Myr}$ in our long $38 \mathrm{Myr}$ simulation when $\mathrm{CO}_{2}$ levels are below $450 \mathrm{ppm}$ to compensate for the higher temperatures. We have therefore retuned the model by changing the uncertain cloud optical thickness parameter. This leads to lower temperatures at the same $\mathrm{CO}_{2}$ levels, such that higher $\mathrm{CO}_{2}$ concentrations are sufficient to obtain the same temperatures. After retuning, the simulated $\mathrm{CO}_{2}$ over the past 800000 years is in reasonable agreement with the ice core record again. The relations between $\mathrm{CO}_{2}$ and temperature and between high- and low-latitude temperatures are now different. However, the influence of ice sheet- climate interactions on ESS and polar amplification remains qualitatively the same.

As was already demonstrated in Stap et al. (2016b), our model is unable to capture the difference in $\mathrm{CO}_{2}$ suggested by proxy data between the time right before the EoceneOligocene transition $(\sim 34 \mathrm{Myr}$ ago $)$ and during the midMiocene climatic optimum ( $\sim 15 \mathrm{Myr}$ ago $)$. This is because the forcing benthic $\delta^{18} \mathrm{O}$ values are similar during these times. Our simulation of $\mathrm{CO}_{2}$ may be improved by extending the model with more aspects of the climate system, moving towards a full Earth system model. Important aspects hitherto neglected in our model are the effects of dynamic vegetation (e.g. Knorr et al., 2011; Liakka et al., 2014; Hamon et al., 2012) and changing topographic boundary conditions as a result of tectonics and erosion (Wilson et al., 2012; Gasson et al., 2015; Stap et al., 2016b). Ultimately, the model could also be coupled to a carbon cycle model, e.g. BICYCLE (Köhler and Fischer, 2004), in order to simulate climate using only insolation data as input.

In our model, ice volume changes enhance the modelled effect of $\mathrm{CO}_{2}$ on temperature via the ice-albedo and the surface-height-temperature feedbacks, particularly in the regions where the ice sheets are located. At low $\mathrm{CO}_{2}$ values, the Northern Hemisphere ice sheets change in size, causing large fluctuations in the temperature in this hemisphere. The ice-albedo feedback is much stronger than the surfaceheight-temperature feedback in these conditions (see also Stap et al., 2014). This is reflected in the Northern Hemisphere $\left(40\right.$ to $\left.80^{\circ} \mathrm{N}\right)$, Antarctic $\left(60\right.$ to $90^{\circ} \mathrm{S}$ ), and global temperature profiles. At intermediate $\mathrm{CO}_{2}$ values, there is only weaker land ice volume variability, as in the Northern Hemisphere there is little land ice left to melt, and in the Southern Hemisphere it is not yet warm enough for the deglaciation of Antarctica. Consequently, temperature changes are only minorly enhanced, both locally and globally. At high $\mathrm{CO}_{2}$ values, the Antarctic ice sheet is more dynamic, so that temperature changes more strongly in the Southern Hemisphere. Here, the impact of the ice-albedo feedback is weaker, since most of the continent remains snow covered during large parts of the year when the ice sheet retreats. Hence, the surface-height-temperature feedback becomes relatively more important. When the ice sheets are kept constant, temperature perturbations are much less strong and more uniformly distributed over the globe.

Data availability. The main model results displayed in this paper are available at https://doi.org/10.1594/PANGAEA.880772 in the Pangaea database. For more information or data, please contact the authors.

\section{The Supplement related to this article is available online at https://doi.org/10.5194/cp-13-1243-2017-supplement.}


Author contributions. LBS, RSWvdW, and BdB designed the research. BdB, RB, and LBS developed the model. LBS conducted the model runs and analysis, to which RSWvdW and BdB contributed. LBS drafted the paper with contributions from all coauthors.

Competing interests. The authors declare that they have no conflict of interest.

Acknowledgements. We thank four anonymous reviewers for providing useful suggestions, which helped to improve the quality of the paper. We further thank Edward Gasson for sharing his data. Financial support for Lennert B. Stap was provided by the Netherlands Organisation of Scientific Research (NWO), grant NWO-ALW. Bas de Boer is funded by NWO Earth and Life Sciences (ALW), project 863.15.019. This paper contributes to the gravity programme "Reading the past to project the future" funded by the Netherlands Organisation for Scientific Research (NWO).

Edited by: Zhengtang Guo

Reviewed by: four anonymous referees

\section{References}

Badger, M. P. S., Schmidt, D. N., Mackensen, A., and Pancost, R. D.: High-resolution alkenone palaeobarometry indicates relatively stable $\mathrm{pCO}_{2}$ during the Pliocene (3.3-2.8 Ma), Philos. T. Roy. Soc. A, 371, 20130094, https://doi.org/10.1098/rsta.2013.0094, 2013.

Beerling, D. J. and Royer, D. L.: Convergent Cenozoic $\mathrm{CO}_{2}$ history, Nat. Geosci., 4, 418-420, 2011.

Berger, A., Li, X. S., and Loutre, M.-F.: Modelling Northern Hemisphere ice volume over the last 3Ma, Quaternary Sci. Rev., 18, 1-11, 1999.

Bintanja, R.: The parameterization of shortwave and longwave radiative fluxes for use in zonally averaged climate models, J. Climate, 9, 439-454, 1996.

Bintanja, R.: Sensitivity experiments performed with an energy balance atmosphere model coupled to an advection-diffusion ocean model, Theor. Appl. Climatol., 56, 1-24, 1997.

Bintanja, R. and Oerlemans, J.: The effect of reduced ocean overturning on the climate of the Last Glacial Maximum, Clim. Dynam., 12, 523-533, 1996.

Bintanja, R. and Van de Wal, R. S. W.: North American ice-sheet dynamics and the onset of 100,000-year glacial cycles, Nature, 454, 869-872, 2008.

Bintanja, R., van de Wal, R. S. W., and Oerlemans, J.: Modelled atmospheric temperatures and global sea levels over the past million years, Nature, 437, 125-128, 2005.

Botsyun, S., Sepulchre, P., Risi, C., and Donnadieu, Y.: Impacts of Tibetan Plateau uplift on atmospheric dynamics and associated precipitation $\delta^{18} \mathrm{O}$, Clim. Past, 12, 1401-1420, https://doi.org/10.5194/cp-12-1401-2016, 2016.

Chappell, J. and Shackleton, N. J.: Oxygen isotopes and sea level, Nature, 324, 137-140, 1986.
Cramer, B. S., Toggweiler, J. R., Wright, J. D., Katz, M. E., and Miller, K. G.: Ocean overturning since the Late Cretaceous: inferences from a new benthic foraminiferal isotope compilation, Paleoceanography, 24, PA4216, https://doi.org/10.1029/2008PA001683, 2009.

Cuffey, K. M.: Methodology for use of isotopic climate forcings in ice sheet models, Geophys. Res. Lett., 27, 3065-3068, 2000.

De Boer, B., Van de Wal, R. S. W., Bintanja, R., Lourens, L. J., and Tuenter, E.: Cenozoic global ice-volume and temperature simulations with 1-D ice-sheet models forced by benthic $\delta^{18} \mathrm{O}$ records, Ann. Glaciol., 51, 23-33, 2010.

De Boer, B., Van de Wal, R. S. W., Lourens, L. J., and Bintanja, R.: Transient nature of the Earth's climate and the implications for the interpretation of benthic $\delta^{18} \mathrm{O}$ records, Palaeogeogr. Palaeocl., 335, 4-11, 2012.

De Boer, B., Van de Wal, R. S. W., Lourens, L. J., Bintanja, R., and Reerink, T. J.: A continuous simulation of global ice volume over the past 1 million years with 3-D ice-sheet models, Clim. Dynam., 41, 1365-1384, 2013.

De Boer, B., Lourens, L. J., and Van de Wal, R. S. W.: Persistent 400,000-year variability of Antarctic ice volume and the carbon cycle is revealed throughout the Plio-Pleistocene, Nat. Commun., 5, 2999, https://doi.org/10.1038/ncomms3999, 2014.

DeConto, R. M. and Pollard, D.: Rapid Cenozoic glaciation of Antarctica induced by declining atmospheric $\mathrm{CO}_{2}$, Nature, 421 , 245-249, 2003.

DeConto, R. M., Pollard, D., Wilson, P. A., Pälike, H., Lear, C. H., and Pagani, M.: Thresholds for Cenozoic bipolar glaciation, Nature, 455, 652-656, 2008.

Duplessy, J.-C., Labeyrie, L., and Waelbroeck, C.: Constraints on the ocean oxygen isotopic enrichment between the Last Glacial Maximum and the Holocene: Paleoceanographic implications, Quaternary Sci. Rev., 21, 315-330, 2002.

Elderfield, H., Ferretti, P., Greaves, M., Crowhurst, S., McCave, I. N., Hodell, D., and Piotrowski, A. M.: Evolution of ocean temperature and ice volume through the Mid-Pleistocene climate transition, Science, 337, 704-709, 2012.

Foster, G. L. and Rohling, E. J.: Relationship between sea level and climate forcing by $\mathrm{CO}_{2}$ on geological timescales, P. Natl. Acad. Sci. USA, 110, 1209-1214, 2013.

Foster, G. L., Lear, C. H., and Rae, J. W. B.: The evolution of $\mathrm{pCO}_{2}$, ice volume and climate during the middle Miocene, Earth Planet. Sc. Lett., 341, 243-254, 2012.

Friedrich, T., Timmermann, A., Tigchelaar, M., Timm, O. E., and Ganopolski, A.: Nonlinear climate sensitivity and its implications for future greenhouse warming, Science Advances, 2, e1501923, https://doi.org/10.1126/sciadv.1501923, 2016.

Ganopolski, A. and Calov, R.: The role of orbital forcing, carbon dioxide and regolith in $100 \mathrm{kyr}$ glacial cycles, Clim. Past, 7, 1415-1425, https://doi.org/10.5194/cp-7-1415-2011, 2011.

Gasson, E.: The past relationship between temperature and sea level - from proxy records and ice sheet modeling, PhD thesis, University of Bristol, Bristol, UK, 2013.

Gasson, E., Siddall, M., Lunt, D. J., Rackham, O. J. L., Lear, C. H., and Pollard, D.: Exploring uncertainties in the relationship between temperature, ice volume, and sea level over the past 50 million years, Rev. Geophys., 50, RG1005, https://doi.org/10.1029/2011RG00035, 2012. 
Gasson, E., Lunt, D. J., DeConto, R., Goldner, A., Heinemann, M., Huber, M., LeGrande, A. N., Pollard, D., Sagoo, N., Siddall, M., Winguth, A., and Valdes, P. J.: Uncertainties in the modelled $\mathrm{CO}_{2}$ threshold for Antarctic glaciation, Clim. Past, 10, 451-466, https://doi.org/10.5194/cp-10-451-2014, 2014.

Gasson, E., DeConto, R. M., and Pollard, D.: Antarctic bedrock topography uncertainty and ice sheet stability, Geophys. Res. Lett., 42, 5372-5377, 2015.

Gasson, E., DeConto, R. M., Pollard, D., and Levy, R. H.: Dynamic Antarctic ice sheet during the early to mid-Miocene, $\mathrm{P}$. Natl. Acad. Sci. USA, 113, 3459-3464, 2016.

Greenop, R., Foster, G. L., Wilson, P. A., and Lear, C. H.: Middle Miocene climate instability associated with high-amplitude $\mathrm{CO}_{2}$ variability, Paleoceanography, 29, 845-853, 2014.

Hamon, N., Sepulchre, P., Donnadieu, Y., Henrot, A.-J., François, L., Jaeger, J.-J., and Ramstein, G.: Growth of subtropical forests in Miocene Europe: the roles of carbon dioxide and Antarctic ice volume, Geology, 40, 567-570, 2012.

Hamon, N., Sepulchre, P., Lefebvre, V., and Ramstein, G.: The role of eastern Tethys seaway closure in the Middle Miocene Climatic Transition (ca. 14 Ma), Clim. Past, 9, 2687-2702, https://doi.org/10.5194/cp-9-2687-2013, 2013.

Hansen, J., Sato, M., Russell, G., and Kharecha, P.: Climate sensitivity, sea level and atmospheric carbon dioxide, Philos. T. Roy. Soc. A, 371, 20120294, https://doi.org/10.1098/rsta.2012.0294, 2013.

Haywood, A. M., Dowsett, H. J., Dolan, A. M., Rowley, D., Abe-Ouchi, A., Otto-Bliesner, B., Chandler, M. A., Hunter, S. J., Lunt, D. J., Pound, M., and Salzmann, U.: The Pliocene Model Intercomparison Project (PlioMIP) Phase 2: scientific objectives and experimental design, Clim. Past, 12, 663-675, https://doi.org/10.5194/cp-12-663-2016, 2016.

Herbert, T. D., Lawrence, K. T., Tzanova, A., Peterson, L. C., Caballero-Gill, R., and Kelly, C. S.: Late Miocene global cooling and the rise of modern ecosystems, Nat. Geosci., 9, 843-847, https://doi.org/10.1038/ngeo2813, 2016.

Hönisch, B., Hemming, N. G., Archer, D., Siddall, M., and McManus, J. F.: Atmospheric carbon dioxide concentration across the mid-Pleistocene transition, Science, 324, 1551-1554, 2009.

Kendall, R. A., Mitrovica, J. X., and Milne, G. A.: On post-glacial sea level-I I. Numerical formulation and comparative results on spherically symmetric models, Geophys. J. Int., 161, 679-706, 2005.

Kennett, J. P.: Cenozoic evolution of Antarctic glaciation, the circum-Antarctic Ocean, and their impact on global paleoceanography, J. Geophys. Res., 82, 3843-3860, 1977.

Knorr, G., Butzin, M., Micheels, A., and Lohmann, G.: A warm Miocene climate at low atmospheric $\mathrm{CO}_{2}$ levels, Geophys. Res. Lett., 38, L20701, https://doi.org/10.1029/2011GL048873, 2011.

Köhler, P. and Fischer, H.: Simulating changes in the terrestrial biosphere during the last glacial/interglacial transition, Global Planet. Change, 43, 33-55, 2004.

Köhler, P., de Boer, B., von der Heydt, A. S., Stap, L. B., and van de Wal, R. S. W.: On the state dependency of the equilibrium climate sensitivity during the last 5 million years, Clim. Past, 11, 1801-1823, https://doi.org/10.5194/cp-11-1801-2015, 2015.

Kominz, M. A., Browning, J. V., Miller, K. G., Sugarman, P. J., Mizintseva, S., and Scotese, C. R.: Late Cretaceous to Miocene sea-level estimates from the New Jersey and Delaware coastal plain coreholes: an error analysis, Basin Res., 20, 211-226, 2008.

Kürschner, W. M.: Leaf stomata as biosensors of palaeoatmospheric $\mathrm{CO}_{2}$ levels, LPP Contributions Series, 5, 1-153, 1996.

Kürschner, W. M., Kvaček, Z., and Dilcher, D. L.: The impact of Miocene atmospheric carbon dioxide fluctuations on climate and the evolution of terrestrial ecosystems, P. Natl. Acad. Sci. USA, 105, 449-453, 2008.

Kutzbach, J. E., Prell, W. L., and Ruddiman, W. F.: Sensitivity of Eurasian climate to surface uplift of the Tibetan Plateau, J. Geol., 101, 177-190, 1993.

Ladant, J.-B., Donnadieu, Y., Lefebvre, V., and Dumas, C.: The respective role of atmospheric carbon dioxide and orbital parameters on ice sheet evolution at the EoceneOligocene transition, Paleoceanography, 29, 810-823, https://doi.org/10.1002/2013PA002593, 2014.

Langebroek, P. M., Paul, A., and Schulz, M.: Simulating the sea level imprint on marine oxygen isotope records during the middle Miocene using an ice sheet-climate model, Paleoceanography, 25, PA4203, https://doi.org/10.1029/2008PA001704, 2010.

Laskar, J., Robutel, P., Joutel, F., Gastineau, M., Correia, A. C. M., and Levrard, B.: A long-term numerical solution for the insolation quantities of the Earth, Astron. Astrophys., 428, 261-285, 2004.

Lear, C. H., Elderfield, H., and Wilson, P. A.: Cenozoic deep-sea temperatures and global ice volumes from $\mathrm{Mg} / \mathrm{Ca}$ in benthic foraminiferal calcite, Science, 287, 269-272, 2000.

Lhomme, N., Clarke, G. K. C., and Ritz, C.: Global budget of water isotopes inferred from polar ice sheets, Geophys. Res. Lett., 32, L20502, https://doi.org/10.1029/2005GL023774, 2005.

Liakka, J., Colleoni, F., Ahrens, B., and Hickler, T.: The impact of climate-vegetation interactions on the onset of the Antarctic ice sheet, Geophys. Res. Lett., 41, 1269-1276, 2014.

Lisiecki, L. E. and Raymo, M. E.: A Pliocene-Pleistocene stack of 57 globally distributed benthic $\delta^{18} \mathrm{O}$ records, Paleoceanography, 20, PA1003, https://doi.org/10.1029/2004PA001071, 2005.

Lucarini, V. and Ragone, F.: Energetics of climate models: Net energy balance and meridional enthalpy transport, Rev. Geophys., 49, RG1001, https://doi.org/10.1029/2009RG000323, 2011.

Lüthi, D., Le Floch, M., Bereiter, B., Blunier, T., Barnola, J.-M., Siegenthaler, U., Raynaud, D., Jouzel, J., Fischer, H., Kawamura, K., and Stocker, T. F.: High-resolution carbon dioxide concentration record 650,000-800,000 years before present, Nature, 453, 379-382, 2008.

Martínez-Botí, M., Foster, G., Chalk, T., Rohling, E., Sexton, P., Lunt, D., Pancost, R., Badger, M., and Schmidt, D.: PlioPleistocene climate sensitivity evaluated using high-resolution $\mathrm{CO}_{2}$ records, Nature, 518, 49-54, 2015.

Miller, K. G., Kominz, M. A., Browning, J. V., Wright, J. D., Mountain, G. S., Katz, M. E., Sugarman, P. J., Cramer, B. S., ChristieBlick, N., and Pekar, S. F.: The Phanerozoic record of global sea-level change, Science, 310, 1293-1298, 2005.

Mitrovica, J. X. and Milne, G. A.: On post-glacial sea level: I. General theory, Geophys. J. Int., 154, 253-267, 2003.

Mudelsee, M., Bickert, T., Lear, C. H., and Lohmann, G.: Cenozoic climate changes: a review based on time series analysis of marine benthic $\delta^{18} \mathrm{O}$ records, Rev. Geophys., 52, 333-374, 2014.

Mulitza, S., Prange, M., Stuut, J.-B., Zabel, M., von Dobeneck, T., Itambi, A. C., Nizou, J., Schulz, M., and Wefer, G.: 
Sahel megadroughts triggered by glacial slowdowns of Atlantic meridional overturning, Paleoceanography, 23, PA4206, https://doi.org/10.1029/2008PA001637, 2008.

Myhre, G., Highwood, E. J., Shine, K. P., and Stordal, F.: New estimates of radiative forcing due to well mixed greenhouse gases, Geophys. Res. Lett., 25, 2715-2718, 1998.

North, G. R.: Theory of energy-balance climate models, J. Atmos. Sci., 32, 2033-2043, 1975.

Oerlemans, J.: Correcting the Cenozoic $\delta^{18} \mathrm{O}$ deep-sea temperature record for Antarctic ice volume, Palaeogeogr. Palaeocl., 208, 195-205, 2004.

Pagani, M., Arthur, M. A., and Freeman, K. H.: Miocene evolution of atmospheric carbon dioxide, Paleoceanography, 14, 273-292, 1999.

Pagani, M., Huber, M., Liu, Z., Bohaty, S. M., Henderiks, J., Sijp, W., Krishnan, S., and DeConto, R. M.: The role of carbon dioxide during the onset of Antarctic glaciation, Science, 334, 1261-1264, 2011.

PALAEOSENS Project Members: Making sense of palaeoclimate sensitivity, Nature, 491, 683-691, 2012.

Pearson, P. N., Foster, G. L., and Wade, B. S.: Atmospheric carbon dioxide through the Eocene-Oligocene climate transition, Nature, 461, 1110-1113, 2009.

Petit, J.-R., Jouzel, J., Raynaud, D., Barkov, N. I., Barnola, J.-M., Basile, I., Bender, M., Chappellaz, J., Davis, M., Delaygue, G., Delmotte, M., Kotlyakov, V. M., Legrand, M., Lipenkov, Y., V., Lorius, C., Pepin, L., Ritz, C., E., S., and Stievenard, M.: Climate and atmospheric history of the past 420,000 years from the Vostok ice core, Antarctica, Nature, 399, 429-436, 1999.

Pollard, D.: A retrospective look at coupled ice sheet-climate modeling, Climatic Change, 100, 173-194, 2010.

Pollard, D. and DeConto, R. M.: Hysteresis in Cenozoic Antarctic ice-sheet variations, Global Planet. Change, 45, 9-21, 2005.

Pollard, D. and DeConto, R. M.: Modelling West Antarctic ice sheet growth and collapse through the past five million years, Nature, 458, 329-332, 2009.

Pollard, D. and DeConto, R. M.: Description of a hybrid ice sheetshelf model, and application to Antarctica, Geosci. Model Dev., 5, 1273-1295, https://doi.org/10.5194/gmd-5-1273-2012, 2012.

Pollard, D., Kump, L. R., and Zachos, J. C.: Interactions between carbon dioxide, climate, weathering, and the Antarctic ice sheet in the earliest Oligocene, Global Planet. Change, 111, 258-267, 2013

Pollard, D., DeConto, R. M., and Alley, R. B.: Potential Antarctic Ice Sheet retreat driven by hydrofracturing and ice cliff failure, Earth Planet. Sc. Lett., 412, 112-121, 2015.

Retallack, G. J.: Greenhouse crises of the past 300 million years, Geol. Soc. Am. Bull., 121, 1441-1455, 2009.

Ritz, S. P., Stocker, T. F., and Joos, F.: A coupled dynamical oceanenergy balance atmosphere model for paleoclimate studies, J. Climate, 24, 349-375, 2011.

Rohling, E. J., Grant, K., Bolshaw, M., Roberts, A. P., Siddall, M., Hemleben, C., and Kucera, M.: Antarctic temperature and global sea level closely coupled over the past five glacial cycles, Nat. Geosci., 2, 500-504, https://doi.org/10.1038/ngeo557, 2009.

Rohling, E. J., Foster, G. L., Grant, K. M., Marino, G., Roberts, A. P., Tamisiea, M. E., and Williams, F.: Sea-level and deep-sea-temperature variability over the past 5.3 million years, Nature, 508, 477-482, 2014.
Russell, G. L., Miller, J. R., and Rind, D.: A coupled atmosphereocean model for transient climate change studies, Atmos. Ocean, 33, 683-730, 1995.

Siegenthaler, U., Stocker, T. F., Monnin, E., Lüthi, D., Schwander, J., Stauffer, B., Raynaud, D., Barnola, J.-M., Fischer, H., Masson-Delmotte, V., and Jouzel, J.: Stable carbon cycleclimate relationship during the late Pleistocene, Science, 310, 1313-1317, 2005.

Sosdian, S. and Rosenthal, Y.: Deep-sea temperature and ice volume changes across the Pliocene-Pleistocene climate transitions, Science, 325, 306-310, 2009.

Stap, L. B., van de Wal, R. S. W., de Boer, B., Bintanja, R., and Lourens, L. J.: Interaction of ice sheets and climate during the past 800000 years, Clim. Past, 10, 2135-2152, https://doi.org/10.5194/cp-10-2135-2014, 2014.

Stap, L. B., De Boer, B., Ziegler, M., Bintanja, R., Lourens, L. J., and Van de Wal, R. S. W.: $\mathrm{CO}_{2}$ over the past 5 million years: continuous simulation and new $\delta^{11} \mathrm{~B}$-based proxy data, Earth Planet. Sc. Lett., 439, 1-10, 2016 a.

Stap, L. B., Van de Wal, R. S. W., De Boer, B., Bintanja, R., and Lourens, L. J.: The MMCO-EOT conundrum: same benthic $\delta^{18} \mathrm{O}$, different $\mathrm{CO}_{2}$, Paleoceanography, 31, 1270-1282, https://doi.org/10.1002/2016PA002958, 2016b.

Tigchelaar, M., von der Heydt, A. S., and Dijkstra, H. A.: A new mechanism for the two-step $\delta^{18} \mathrm{O}$ signal at the Eocene-Oligocene boundary, Clim. Past, 7, 235-247, https://doi.org/10.5194/cp-7235-2011, 2011.

Toggweiler, J. R. and Bjornsson, H.: Drake Passage and palaeoclimate, J. Quaternary Sci., 15, 319-328, 2000.

van de Wal, R. S. W., de Boer, B., Lourens, L. J., Köhler, P., and Bintanja, R.: Reconstruction of a continuous high-resolution $\mathrm{CO}_{2}$ record over the past 20 million years, Clim. Past, 7, 1459-1469, https://doi.org/10.5194/cp-7-1459-2011, 2011.

Van der Burgh, J., Visscher, H., Dilcher, D. L., and Kürschner, W. M.: Paleoatmospheric signatures in Neogene fossil leaves, Science, 260, 1788-1788, 1993.

Willeit, M., Ganopolski, A., Calov, R., Robinson, A., and Maslin, M.: The role of $\mathrm{CO}_{2}$ decline for the onset of Northern Hemisphere glaciation, Quaternary Sci. Rev., 119, 22-34, 2015.

Wilson, D. S., Jamieson, S. S. R., Barrett, P. J., Leitchenkov, G., Gohl, K., and Larter, R. D.: Antarctic topography at the EoceneOligocene boundary, Palaeogeogr. Palaeocl., 335, 24-34, 2012.

Wilson, D. S., Pollard, D., DeConto, R. M., Jamieson, S. S. R., and Luyendyk, B. P.: Initiation of the West Antarctic Ice Sheet and estimates of total Antarctic ice volume in the earliest Oligocene, Geophys. Res. Lett., 40, 4305-4309, 2013.

Yoshimori, M., Hargreaves, J. C., Annan, J. D., Yokohata, T., and Abe-Ouchi, A.: Dependency of feedbacks on forcing and climate state in physics parameter ensembles, J. Climate, 24, 6440-6455, 2011.

Zachos, J. C., Dickens, G. R., and Zeebe, R. E.: An early Cenozoic perspective on greenhouse warming and carbon-cycle dynamics, Nature, 451, 279-283, 2008.

Zhang, X., Lohmann, G., Knorr, G., and Purcell, C.: Abrupt glacial climate shifts controlled by ice sheet changes, Nature, 512, 290 294, https://doi.org/10.1038/nature13592, 2014. 